\title{
Phase1 Can-in-Canister Cold Pour Tests for the Plutonium Immobilization Project
}

by

M. E. Smith

Westinghouse Savannah River Company

Savannah River Site

Aiken, South Carolina 29808

RECEIVED

G. L. Hovis

This paper was prepared in connection with work done under the above contract number with the U. S.

Department of Energy. By acceptance of this paper, the publisher and/or recipient acknowledges the U. S. Government's right to retain a nonexclusive, royalty-free license in and to any copyright covering this paper, along with the right to reproduce and to authorize others to reproduce all or part of the copyrighted paper. 


\section{Phase 1 Can-in-Canister Cold Pour Tests for the Plutonium Immobilization Project (U)}

Michael E. Smith and Gregory L. Hovis Westinghouse Savannah River Company Savannah River Technology Center Aiken, SC 29808 


\section{DISCLAIMER}

This report was prepared as an account of work sponsored by an agency of the United States Government. Neither the United States Government nor any agency thereof, nor any of their employees, makes any warranty, express or implied, or assumes any legal liability or responsibility for the accuracy, completeness, or usefulness of any information, apparatus, product or process disclosed, or represents that its use would not infringe privately owned rights. Reference herein to any specific commercial product, process or service by trade name, trademark, manufacturer, or otherwise does not necessarily constitute or imply its endorsement, recommendation, or favoring by the United States Government or any agency thereof. The views and opinions of authors expressed herein do not necessarily state or reflect those of the United States Government or any agency thereof.

This report has been reproduced directly from the best available copy.

Available for sale to the public, in paper, from: U.S. Department of Commerce, National Technical Information Service, 5285 Port Royal Road, Springfield, VA 22161, phone: (800) 553-6847

fax: (703) 605-6900

email: orders@ntis.fedworld.gov

online ordering: http://www.ntis.gov/ordering.htm

Available electronically at http://www.doe.gov/bridge

Available for a processing fee to U.S. Department of Energy and its contractors, in paper, from: U.S. Department of Energy, Office of Scientific and Technical Information, P.O. Box 62, Oak Ridge, TN 37831-0062, phone: (865) 576-8401

fax: (865) 576-5728

email: reports@adonis.osti.gov 


\section{DISCLAIMER}

Portions of this document may be illegible in electronic image products. Images are produced from the best available original document. 


\section{Phase 1 Can-in-Canister Cold Pour Tests for the Plutonium Immobilization Project (U)}

Michael E. Smith and Gregory L. Hovis Westinghouse Savannah River Company Savannah River Technology Center Aiken, SC 29808

Westinghouse Savannah River Company Savannah River Site 


\section{Approvals}

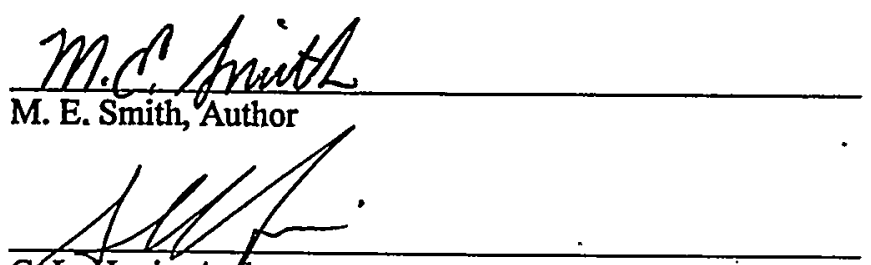

G.L. Hovis, Author

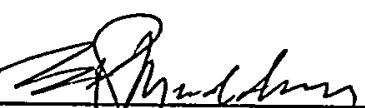

E. P. Maddux, Technical Reviewer SRS/NMSS/FMP

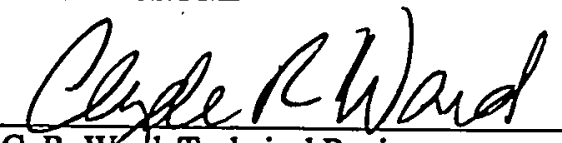

C. R. Wart, Technical Reviewer

SRTC, Engineered Equipment and Systems

Samer C. Mana

J. E. Marra, Plutonium Immobilization Program Manager SRTC, Immobilization Technology Section

Eu stoltzacheto

E. W. Holtzscheiter, Level 3 Manager

SRTC, Immobilization Technology Section

Authorized Derivative Classifier

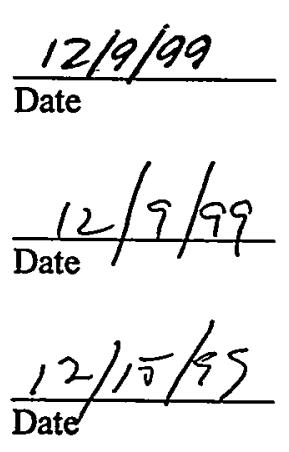

$\frac{12 / 15 / 99}{\text { Date }}$

$\frac{i 2-15-99}{\text { Date }}$

$\frac{12-9-99}{\text { Date }}$ 


\section{Contents}

Approvals $\quad$. ii

Contents iii

1.0 Introduction 1

2.0 Phase 1 Test Strategy 2

3.0 Can-in-Canister Hardware Configurations 3

4.0 Pre-Phase 1 Test Pours 6

$\begin{array}{ll}\text { 5.0 Phase } 1 \text { Cold Pour Tests } & 6\end{array}$

5.1 General Test Information $\quad 6$

5.2 Canister Configuration 1 Test-Partial Fill/Low Pour Rate $\quad 8$

5.3 Canister Configuration 3 Test - Complete Fill/Normal Pour Rate 9

5.4 Canister Configuration 2 Test - Complete Fill/Normal Pour Rate $\quad 10$

6.0 Instrumented Canister (Configuration 2) Temperature Results $\quad 12$

$\begin{array}{ll}\text { 7.0 Canister Sectioning } & 16\end{array}$

7.1 Configuration 3 Canister Sectioning $\quad 16$

$\begin{array}{ll}\text { 7.2 Configuration 1 Canister Sectioning } & 17\end{array}$

$\begin{array}{ll}\text { 7.3 Configuration 2 Canister Sectioning } & 17\end{array}$

$\begin{array}{ll}7.4 \text { Post Section Hardware Analysis } & 17\end{array}$

$\begin{array}{ll}8.0 \text { Canister Glass Samples } & 17\end{array}$

$\begin{array}{llll}9.0 \text { Conclusions } & \cdot & 18\end{array}$

$\begin{array}{ll}\text { 10.0 Acknowledgements } & 19\end{array}$

$\begin{array}{ll}11.0 \text { References } & 19\end{array}$

$\begin{array}{ll}12.0 \text { Attachments } & 20\end{array}$

12.1 Phase 1 Experimental Test Plan (SRT-GFM-98-0040)

12.2 Phase 1 Post-Pour Analysis (SRT-RSE-99-00056) 


\subsection{Introduction}

The Plutonium Immobilization Project (PIP) is a program funded by the U.S. Department of Energy (DOE) to develop the technology to disposition excess weapons grade plutonium. Lawrence Livermore National Laboratory (LLNL) is the lead laboratory for the program with the Savannah River Site (SRS) partnering on key technical and engineering aspects of the program. In the two-part can-in-canister (CIC) approach, plutonium is immobilized at a nominal 10 weight percent concentration within titanate-based ceramic forms (pucks). The pucks are sealed in stainless steel cans and then loaded into long cylindrical magazines. These magazines are latched to racks inside Defense Waste Processing Facility (DWPF) canisters that will be filled with High Level Waste (HLW) glass at the DWPF. The ceramic form and the radiation barrier provided by the HLW glass makes the plutonium unattractive to terrorists and for reuse. The can-incanister concept is shown in Figure 1.1.

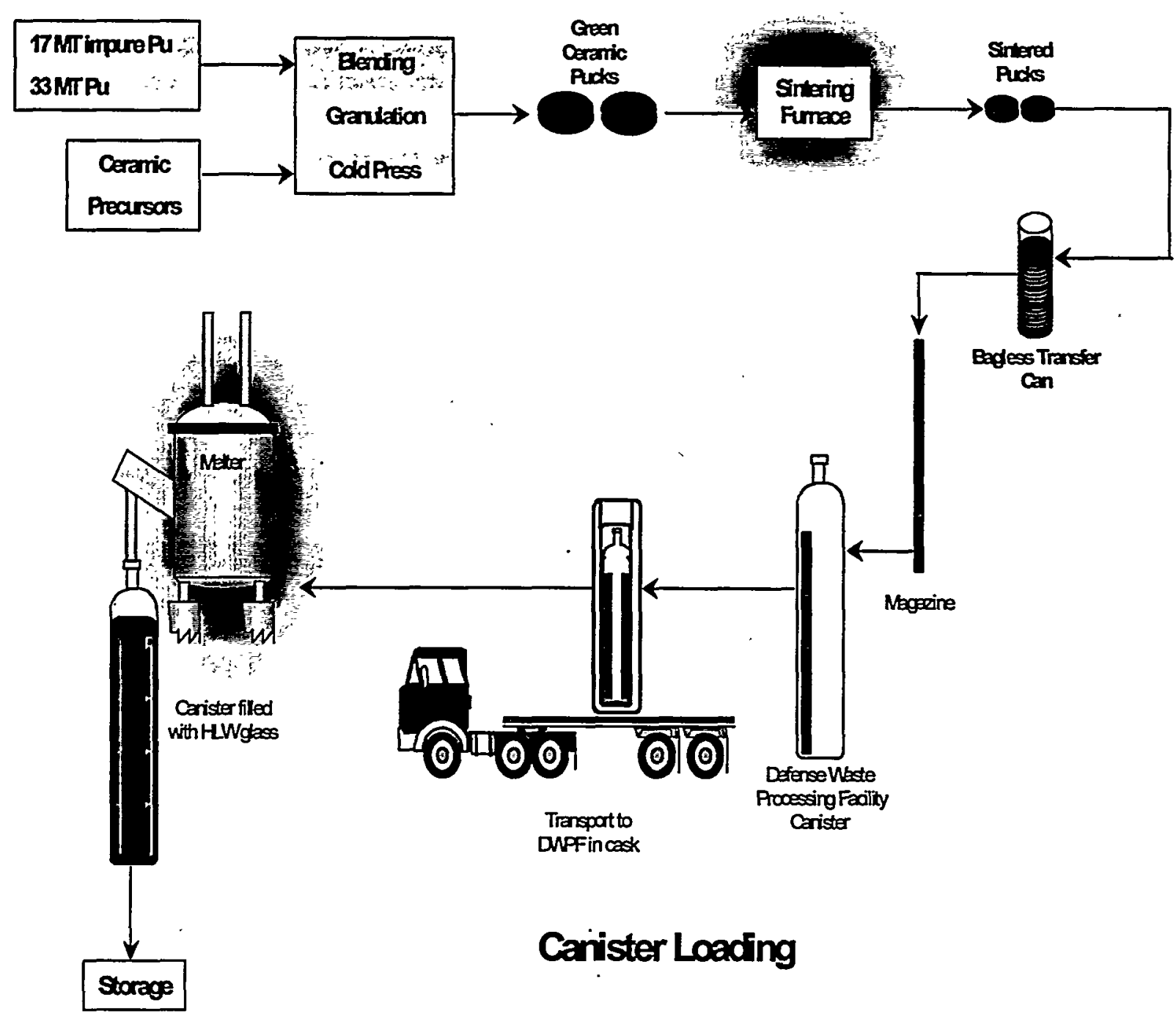

Figure 1.1 Can-in-Canister Approach to Plutonium Immobilization 
Presently the DWPF pours glass into empty canisters. In the can-in-canister approach, the addition of a stainless steel rack, magazines, cans, and ceramic pucks to the canisters introduces a new set of design and operational challenges. Namely, all of the hardware installed in the canisters must maintain structural integrity at elevated (molten glass) temperatures. This suggests that a robust design is required. However, the amount of material added to the DWPF canister must be minimized to prevent premature glass cooling which could result in excessive voiding caused by a large internal thermal mass.

In addition to remote operation considerations, high metal temperatures, minimizing thermal mass, and glass voiding were the primary CIC hardware issues. Demonstration of the effectiveness of the design in full scale testing was deemed necessary per task 2.7.1 (Can-in-Canister System) of the PIP Integrated Development and Testing Plan. These tests are done using non-radioactive glass and are called cold pour tests. The cold pour tests were planned for two phases. Phase 1 consists of test pours and thermal modeling to evaluate preliminary equipment designs (cans, magazines, and racks), as well as identify any changes that are required to establish a firm baseline design. The Phase 1 Test pours are intended to provide scoping quality verification of design concepts prior to the more extensive and quality controlled Phase 2 Tests. The Phase 2 Tests will incorporate changes based on the results of the Phase 1 Tests and will verify the adequacy of the baseline design for the start of Title 1 plant design. If necessary, additional tests may be required to validate any subsequent design changes or address additional regulatory concems.

This report discusses the Phase 1 Tests. Details on the test plan, hardware configuration, and test results are given.

\subsection{Phase 1 Test Plan Strategy}

The details of the Phase 1 Test are discussed in the attached test plan entitled "Experimental Test Plan for Phase 1 of the PIP Can-in-Canister Cold Pour Tests" (SRT-GFM-98-0040, Rev. 0). The main test parameters controlled were the pour rate, glass composition, glass stream temperature, glass stream fall height, hardware configurations, and glass fill height. These parameters are further discussed in the Phase 1 Cold Pour Test section of this report. A Task Technical and Quality Assurance Plan ${ }^{1}$ was also written. The appropriate SRS, SRTC, NMSS, DWPF and LLNL personnel approved both the teșt plan and the Task Technical and Quality Assurance Plan.

The two main items to be investigated in the Phase 1 Test were the extent of glass void formation and the degree of structural deformation of the installed PIP hardware in the DWPF canister that occurred after being filled with glass. Although no acceptance criteria was given for these items before the Phase 1 Test, all parties involved agreed that a decision could be made from the Phase 1 results to determine the hardware to be tested in Phase 2. Three canisters with installed hardware were determined to be adequate for this assessment.

The Phase 1 Test was scoping in nature and was used to evaluate various rack/magazine configurations. These tests will not be used for waste qualification activities requiring RW-0333P quality assurance controls, but were done under good laboratory practices. The tests were performed at the Clemson Environmental Technologies Laboratory (CETL) under a WSRC South Carolina University Research and Education Foundation (SCUREF) contract. Per the SCUREF Statement of Work, WSRC personnel ran the test with operational support supplied by CETL personnel. The melter used was the Full-Scale Stirred Melter. This melter had been previously installed at the CETL for other DWPF support work and was the only melter available to WSRC that could fill a full sized DWPF canister at the required DWPF pour rates. The SRS notebook used for the test was WSRC-NB-98-00272. 


\subsection{Can-In-Canister Hardware Configurations}

The CIC hardware development program was concerned with both remote loading/handling issues (for actual PIP facility operations) and glass related issues (e.g. glass flow and structural integrity). While a solid pipe magazine with no holes is ideal for remote operations, it does not allow glass to contact the cans. On the other hand, a thin wire magazine provides maximum glass contact with the cans and minimizes thermal mass, yet it is too fragile in the remote environment of the PIP facility. The hardware configurations in the Phase 1 cold pours were designed to address these types of design issues. The objective was to observe the effects of the glass on the hardware, and vise versa. Originally four configurations were proposed, but the number was reduced to three for budget purposes. All three configurations consisted of fully equipped DWPF canisters (i.e. internal rack and full compliment of magazines and cans). The three configurations are discussed in greater detail below.

A total of three rack designs, eight magazine designs, and two lateral latching configurations were tested in the Phase 1 pours. Each rack carried a total of seven magazines, and each magazine held four cans. The cans were loaded with either non-radioactive titanate-based surrogate ceramic pucks fabricated by LLNL, ceramic surrogate logs, or stainless steel bars. The ceramic pucks could not be used exclusively because not enough were available in time for the test. Therefore, ceramic logs (Harbison-Walker Aurex 90 chrome-alumina brick) were used because their thermal properties were similar to the ceramic pucks. These ceramic logs were, however, lighter than the pucks, and therefore stainless steel bars were installed in a total of four cans (two cans each in two different magazines) to assess the effects of a full weight magazine on the loading of a bottom plate. For these tests, the racks were configured with four different magazine types. Three of the magazine types were arranged in pairs (taking up six positions) and a fourth type was placed in the seventh position. Magazine pairing was done to observe glass flow between like magazine types. All internal hardware (rack, magazines, and cans) was made of 304L stainless steel. Further details of the hardware can be found in WRSC notebook WSRC-NB-98-00272 and in SRTC Engineered Equipment and Systems job folder 22624.

Canister hardware was installed by cutting off the top of a DWPF canister just below the shoulder weld using a plasma torch. An empty rack was hoisted into the canister, then magazines were hoisted individually into the rack. Once the rack was loaded, the canister top was re-welded to the canister. For - the purposes of these tests, the re-welded canisters were not required to meet DWPF specifications. Figure 3.1 gives a simulation of the CIC hardware. Figures 3.2 and 3.3 show the installed hardware in canister configurations 3 and 2 , respectively.

\section{Configuration 1}

The racks installed in configurations 1 and 2 were identical with one minor exception. The rack installed in configuration one was equipped with a "top latching plate" which is essentially an extra scalloped plate located near the top of the magazines. Identical magazines were installed in configurations 1 and 2 as well. The hardware in these configurations were favored as the current "baseline" design (i.e. these components meet design objectives and currently have the highest probability of becoming facility design input).

Configuration 1 is a canister with an installed stainless steel rack made of $1 / 4$ " plate with 3/4" support rods. Four different magazine designs were installed (two schedule 10 pipe short slots, two schedule 10 pipe long slots, two 0.065 " wall pipe with 1 " holes, and one Sterling wire form). This configuration used was for the partial height pour at a low glass flow rate.

\section{Configuration 2}

The rack installed in configuration 2 was identical to that in configuration 1 , minus the top latching plate. Magazines were identical to those in configuration 1 . Configuration 2 was fully instrumented (23 thermocouples and a camera) and had a stainless steel rack of $1 / 4$ " plate with $3 / 4$ " supports. Details of the instrumentation are given in section 5.4 of this report. This configuration was for a full height pour at normal DWPF pour conditions. 


\section{Configuration 3}

Configuration 3 is referred to as the "heavy" configuration. It was equipped with a rack made of $3 / 8$ " plate with 1 " support rods. This rack design also had a top latching plate. Five different magazine designs were installed (two schedule 40 pipe short slots, two schedule 40 pipe long slots, one schedule 10 pipe with 1" holes, one schedule 10 pipe short slots, and one Stillwalter wire form). The original plan was to install two schedule 10 pipe magazines with 1 " holes, but only one was available at the time of the installation. Therefore, the second one was replaced with a schedule 10 pipe short slots magazine. This test was designed to provide bounding data in the event that heavier components are required in future rack designs. Like configuration 2, this canister was for a full height pour at normal DWPF pour conditions.

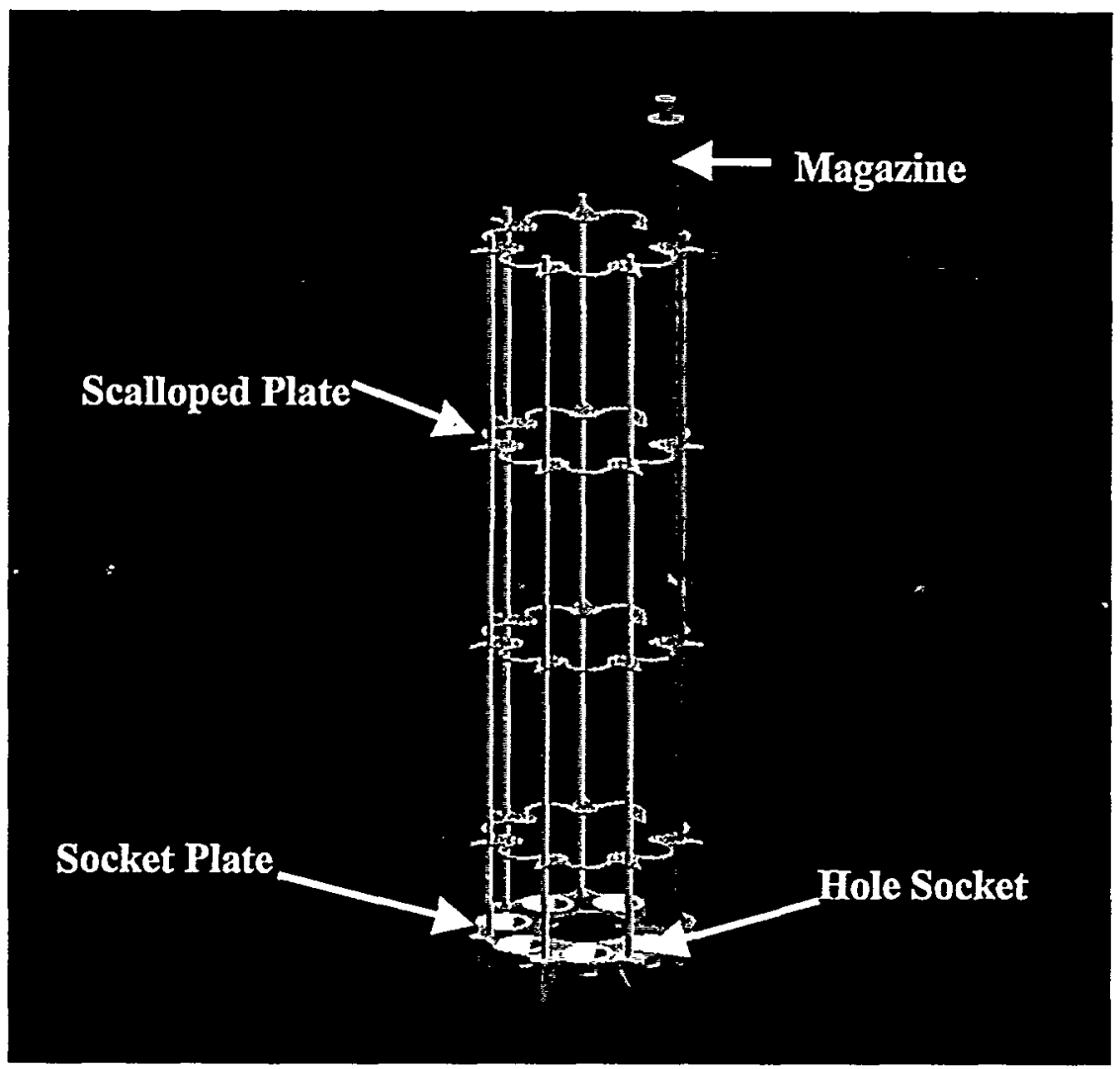

Figure 3.1 Simulation of Can-in-Canister Hardware 


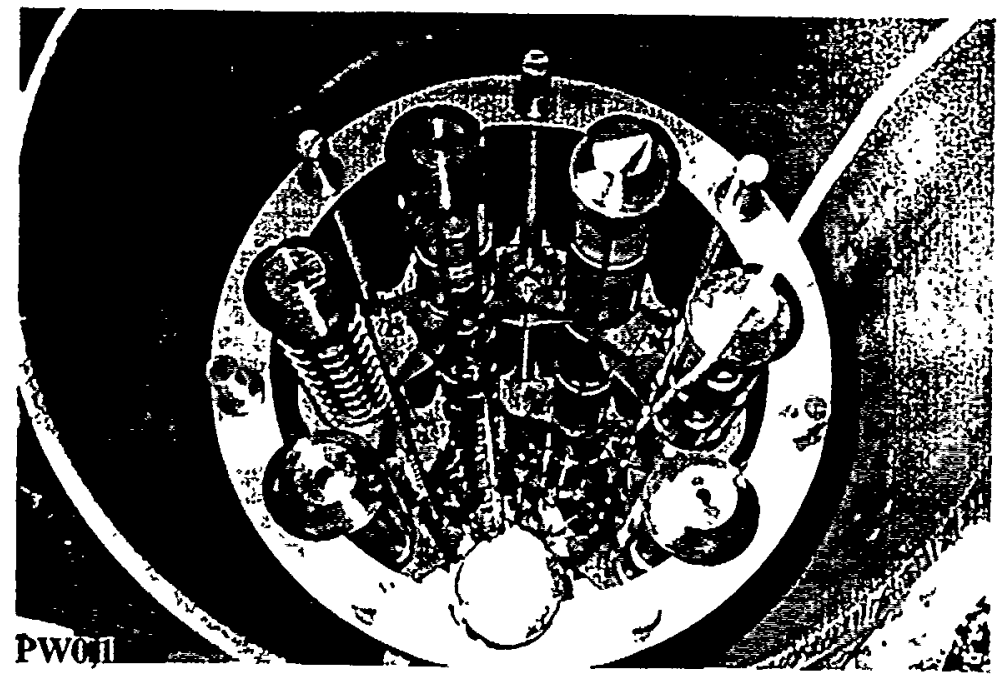

Figure 3.2 - Configuration 3 Hardware Installed in DWPF Canister

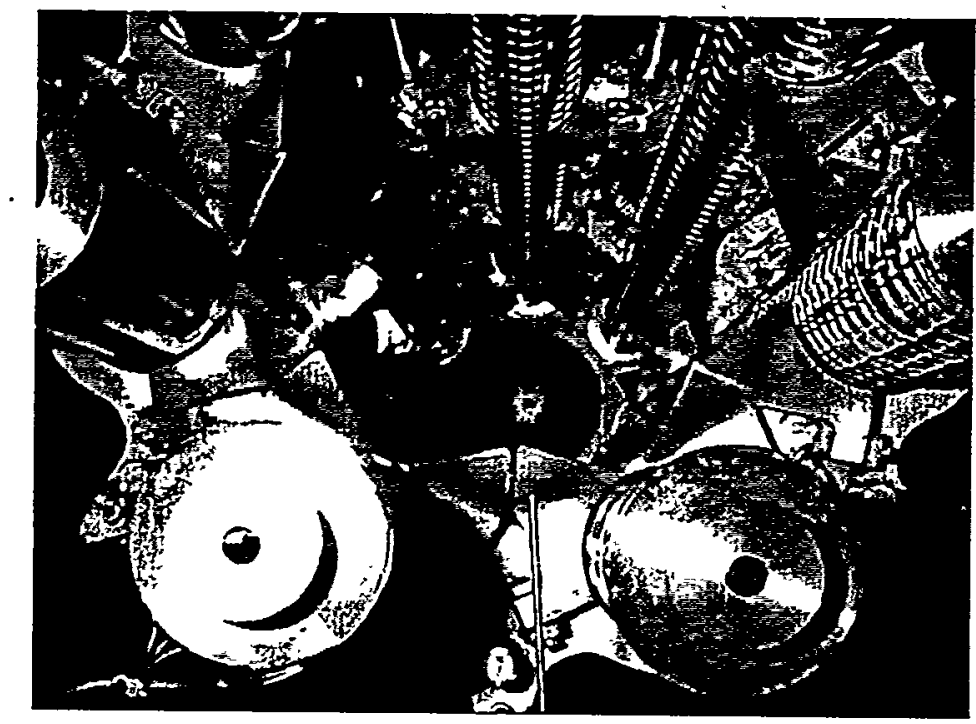

Figure 3.3 - Inside of Instrumented Configuration 2 Canister as Shown by Installed Camera 


\subsection{Pre-Phase 1 Test Pours}

Before beginning the actual Phase 1 Test, a pre-phase 1 test pour was made to see if any glass voiding would occur. This was deemed as a worthy test because of the amount of money that had been spent on planning the Phase 1 Test as well as the design, fabrication, and installation of the canister hardware. The investigators did not want to run the Phase 1 Test if there were strong indications from this pre-test pour that Phase 1 would not be successful. Therefore, a DWPF canister was cut in half and seven PIP cans were installed. The bottom rack was put in place as well to help hold the seven cans in place (see Figure 4.1). This test configuration was placed under the melter and glass poured at approximately $150 \mathrm{lbs} / \mathrm{hr}$ into the canister via the DWPF pour spout test stand at the end of the Tank Focus Area (TFA) run at the CETL in June, 1999. This test was repeated at a pour rate of about $100 \mathrm{lbs} / \mathrm{hr}$ without the DWPF pour spout test stand after the Stirred Melter had been started up for the Phase 1 Test. Both tests showed that no glass voids were formed. The glass used for both of these tests was the same DWPF Cold Run glass (nonradioactive) that was used for the Phase 1 Test.

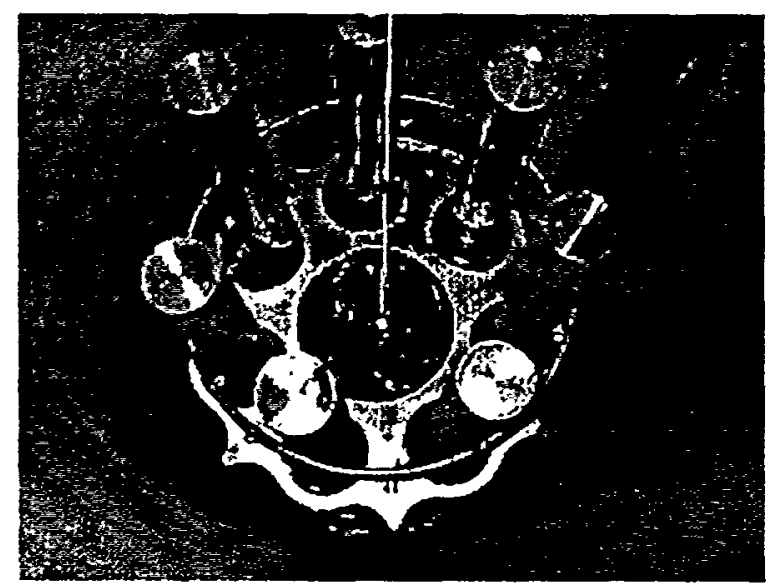

Figure 4.1 Pre-Phase 1 Test Pour at the End of the 6/99 TFA Run

\subsection{Phase 1 Cold Pour Tests}

\subsection{General Test Information}

As stated previously, the DWPF Full-Scale Stirred Melter was used to pour glass into DWPF canisters with different Can-in-Canister hardware configurations per the attached Phase 1 experimental test plan. More details concerning the Stirred Melter can be found elsewhere ${ }^{2}$. Three canisters were filled with glass. The main test parameters controlled were the 1) pour rate, 2) glass composition, 3) glass stream temperature, 4) glass stream fall height, 5) glass fill height, and 6) hardware configurations. By controlling these parameters, the important pour conditions similar to those expected at the DWPF when can-in-canister glass filling are achieved. Below is a discussion of these various controlled test parameters.

Pour rate - Feeding the Stirred Melter with glass at the desired rate controlled the pour rate as the melter was operated in an overflow pour mode. Each of the canisters was placed underneath the superheater section of the Stirred Melter and glass was poured by means of the superheater pour valve. The canisters were placed on a vendor calibrated weigh scale with insulation between the scale and the canister to protect the load cell. The scale was tared before glass pouring was started for each canister. The pour rate was monitored by tracking the change in the weight of the canister over time. These weights were recorded every 5 minutes during glass pouring on a data acquisition system supplied by the SRTC Thermal Fluids 
Laboratory. In addition, periodic glass samples were taken for 18 seconds and then weighed to verify the pour rate.

Glass composition - All of the glass fed into the Stirred Melter was from various DWPF Cold Run canisters. Table 5.1 summarizes the canisters of DWPF glass that were shipped to the CETL for this run.

Table 5.1 - DWPF Canister/Glass Details for Glass Used for Phase 1 Cold Pour Test

\begin{tabular}{|c|c|c|c|c|}
\hline $\begin{array}{c}\text { DWPF } \\
\text { Canister ID }\end{array}$ & DWPF Run & $\begin{array}{c}\text { Predicted Viscosity* } \\
\text { (if available) }\end{array}$ & $\begin{array}{c}\text { Measured Viscosity* } \\
\text { (if available) }\end{array}$ & $\begin{array}{c}\text { Approximate Weight } \\
\text { of Glass (lbs) }\end{array}$ \\
\hline S00409 & WP-17 & $78 / 85$ & - & 4000 \\
\hline S00303 & WP-17 & $80 / 88$ & 79 & 3500 \\
\hline S00310 & WP-17 & $79 / 82$ & 86 & 4000 \\
\hline S00406 & WP-17 & - & 81 & 4000 \\
\hline S00306 & WP-17 & - & 75 & 4000 \\
\hline S00318 & WP-17 & - & 77 & 4000 \\
\hline S00144 & PRO-1/Batch 1 & - & - & 4000 \\
\hline S00134 & PRO-1/Batch 1 & - & - & 1000 \\
\hline S00317 & PRO-2/Batch 1 & - & - & 2500 \\
\hline
\end{tabular}

* Viscosity values are given in poise at $1150^{\circ} \mathrm{C}$. If more than one sample taken, then more than one viscosity value is reported. Runs WP-17, PRO-1/Batch 1 and PRO-2/Batch 1 were done successively and the canisters above are listed in chronological order. Other canisters were filled in these runs (total of nine) but are not listed as those canisters were not shipped to the CETL.

As can be seen, there is no viscosity data for the last three canisters of glass used for the test. However, the measured viscosity from glass in DWPF canister S00312 (three canisters after S00134 and three before S00317) was 66 poise. Therefore the viscosity of the glass in these three canisters can be assumed to be fairly close to the other reported values. In addition, glass samples were planned to be taken from each canister filled during the test and viscosities calculated via the DWPF viscosity algorithm using the measured glass compositions. Glass viscosities of these samples were to be measured as well. Also, much of the glass had already been processed in the melter and therefore was a blend of the all of the glass shipped to the CETL. Finally, all of the glass was ground by a hammer mill so that the material could be fed to the melter via a screw feed auger. This grinding also helped in mixing the glass. With these considerations, all parties involved in this scoping test agreed that the glass was acceptable to use.

Glass stream temperature - Unlike the DWPF Melter, there was no riser/pour spout with the Stirred Melter for this run. Per the Phase 1 experimental test plan, the glass stream temperature was determined by a type $B$ thermocouple that is located in the superheater zone 3 glass pool just before it exists the pour valve and flows into the canister. This temperature was monitored hourly via melter round sheets. The targeted temperature range was 1050 to $1100^{\circ} \mathrm{C}$. This temperature range was achieved for the three pours. In addition, periodic glass stream temperature readings were made just above the top of the canister by an optical pyrometer with an emissivity setting of one. These pyrometer readings were compared to those taken during Scale Glass Melter runs at various pour rates. This data was used as a "sanity check" to determine if the pour temperatures were indeed similar to those expected in the DWPF Melter.

Glass stream fall height - The fall height from the bottom of the pour valve to the bottom of the canister needed to be about the same as in the DWPF Melter. Per the test plan, the distance from the bottom of the pour valve to the top of the canister had to be greater than 10 inches. This distance was measured to be 17.5 inches. This agrees quite well with the gap of 23.4 inches between the bottom of the pour spout and the top of the canister at the DWPF.

Glass fill height - The minimum glass fill height specified for the partial fill canister was 30 inches. For the two full canisters, the minimum fill height was 90 inches. During glass pouring the fill height was 
estimated by observing the height of the oxide layer that formed on the canister surfaces. This was compared to the calculated height of glass per the measured weight of glass poured. After the canisters were filled, the canisters were removed and the actual glass height was determined by inserting a tape measure into the top of the canister until it touched the top of the glass.

Hardware configurations - Each canister had different hardware configurations that were discussed in section 3.0 of the report. Configuration 1 was planned to be a worst case test with regards to glass voids. The canister was to be filled with 30 inches of glass at a targeted pour rate of $100 \mathrm{lbs} / \mathrm{hr}$ (lowest expected pour rate at the DWPF). The configuration 2 and 3 canisters were to be filled completely at nominal DWPF pour rates (target was $200-240 \mathrm{lbs} / \mathrm{hr}$ ). Configuration 2 was instrumented with 23 thermocouples. These thermocouples were welded to the outside surface of the canister, the cans inside the canisters, and inserted in various other positions inside the canister. A camera and light source were also installed on the top of the configuration 2 canister so that the glass pour inside the canister could be monitored and recorded. Figure 5.1 shows a picture of the instrumented canister under the melter.

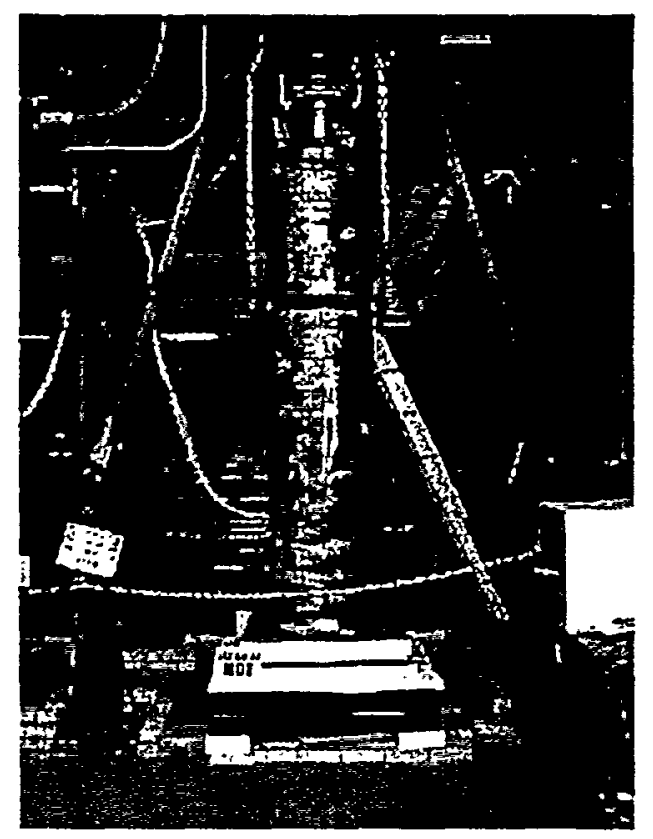

Figure 5.1 - Configuration 2 (Instrumented Canister) under Melter after Completion of Pour

\subsection{Canister Configuration 1 Test- Partial Fill/Low Pour Rate}

The filling of the configuration 1 canister (DWPF canister S00133) was started at 1900 on August 3, 1999. The pour was stopped at 0700 on August 4, 1999. At the time the pour was stopped, the glass weight was 1360 pounds. Glass, however, continued to pour into the canister until 0730 because the pour valve had not been fully closed. The final glass weight at 0723 was 1373 pounds. The overall calculated pour rate was $113 \mathrm{lbs} / \mathrm{hr}$ (not including the last 23 minutes when the pour valve was partially closed). The pour rate was fairly consistent throughout the pour and there were no pour stoppages (see Figure 5.2). After the canister was removed, the actual glass height was measured to be 42 inches. The calculated weight (assuming a glass density $2.64 \mathrm{gm} / \mathrm{cm}^{3}$ ) of glass poured into the canister was about 1399 pounds. This is very close to the actual measured weight of 1373 pounds and implies that there was no significant glass voiding in the canister. 
The measured temperature of the superheater zone 3 melt pool just before the pour valve ranged from 1048 to $1053^{\circ} \mathrm{C}$ during the filling of this canister per the hourly log sheets. In addition, the three pour stream temperatures as measured by an optical pyrometer at various times during the pour were 1009,1023, and $1033^{\circ} \mathrm{C}$. Previous pilot scale work at SRS indicated that the glass stream temperature at a pour rate of 115 $\mathrm{lbs} / \mathrm{hr}$ is about $1025^{\circ} \mathrm{C}$. Therefore, this pour stream appears to have been thermally similar to a DWPF pour at this low pour rate.

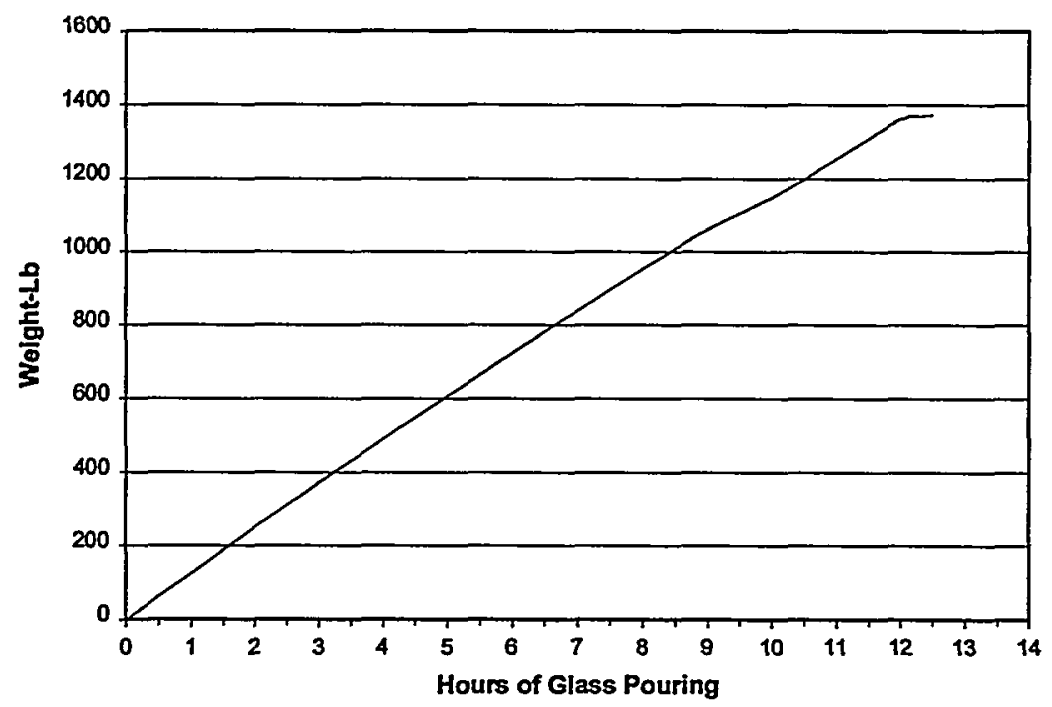

Figure 5.2 - Glass Weight versus Time for Configuration 1 Canister

\subsection{Canister Configuration 3 Test - Complete Fill/Normal Pour Rate}

The filling of the configuration 3 canister (DWPF canister S00003) was started at 0915 on August 4, 1999. The pour was stopped at 0630 on August 5, 1999. The final glass weight was 3353 pounds. The overall calculated pour rate was $158 \mathrm{lbs} / \mathrm{hr}$. There were no pour stoppages (see Figure 5.3). The pour rate was lower than anticipated (targeted rate was above $200 \mathrm{lbs} / \mathrm{hr}$ ) and could not be fixed without shutting the melter down. This shutdown/restart would have taken 4 to 5 days. Also, there were no guarantees that the problem could be quickly solved after this considered shutdown. Therefore the decision was made to continue with the test since the pour rate achieved was in the range that DWPF normally operates.

Troubleshooting on the Stirred Melter was performed after the completion of the Phase 1 Test. The most likely cause of the low pour rate was some black solid material that was partially blocking the pour valve pipe.

After the pour the actual canister glass height was measured to be 97 inches. With the thicker hardware used in configuration 3, each inch of glass in the canister was calculated to be approximately 34.5 pounds. Therefore the calculated glass weight poured into the canister was about 3347 pounds. This is very close to the actual measured weight of 3353 pounds and implies that there was essentially no glass voiding in the canister.

The measured temperature of the superheater zone 3 melt pool just before the pour valve ranged from about 1070 to $1080^{\circ} \mathrm{C}$ during the filling of this canister per the hourly log sheets. In addition, the two pour stream temperatures as measured by an optical pyrometer during the pour were 1061 and $1063^{\circ} \mathrm{C}$. Previous pilot scale work at SRS indicated that the glass stream temperature at a pour rate of $170 \mathrm{lbs} / \mathrm{hr}$ is about $1050^{\circ} \mathrm{C}$. Therefore this pour stream appears to have been thermally similar to a DWPF pour at this pour rate. 


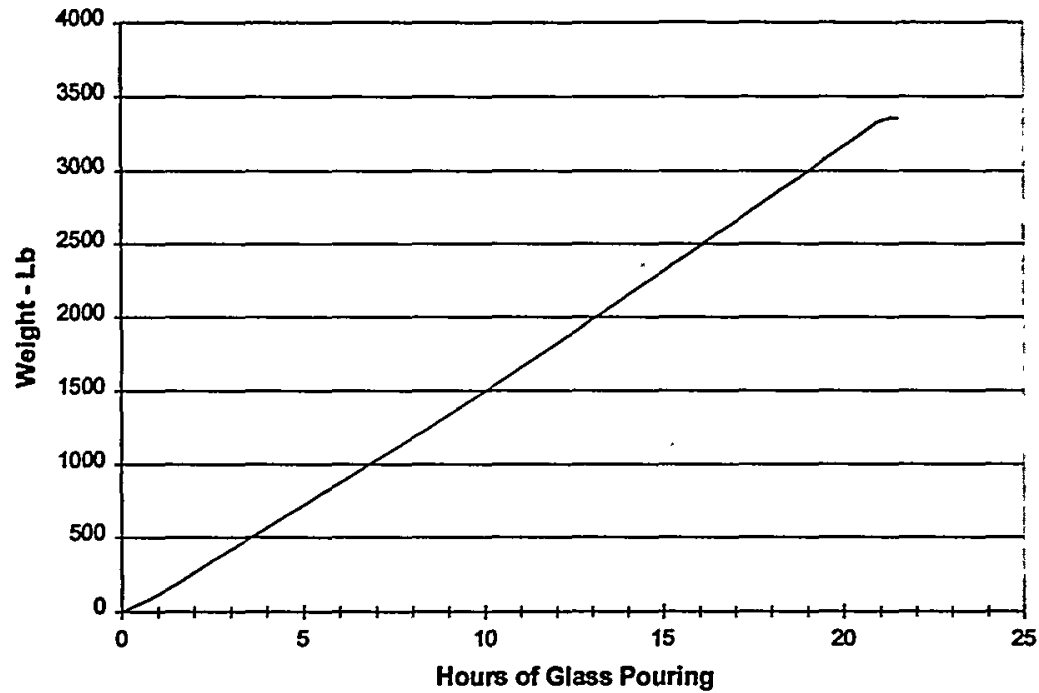

Figure 5.3 - Glass Weight versus Time for Configuration 3 Canister

\subsection{Canister Configuration 2 Test - Complete Fill/Normal Pour Rate}

The filling of the configuration 2 canister (DWPF canister S00167) was started at 1143 on August 5, 1999. The pour was stopped at 0745 on August 6, 1999. The final glass weight was 3250 pounds. The overall calculated pour rate was $163 \mathrm{lbs} / \mathrm{hr}$. There were no pour stoppages (see Figure 5.4). After the canister was removed, the actual glass height was measured to be 94 inches. With the normal hardware used in configuration 2, each inch of glass in the canister was calculated to be about 35.2 pounds. Therefore the calculated glass weight poured into the canister was 3309 pounds. This is very close to the actual measured weight of 3250 pounds and again implies that there was no significant glass voiding in the canister.

The measured temperature of the superheater zone 3 melt pool just before the pour valve was about $1080^{\circ} \mathrm{C}$ during the filling of this canister per the hourly log sheets. Although no optical pyrometer temperature readings were taken on the pour stream, it was determined that the stream appears to have been thermally similar to a DWPF pour at this pour rate. This is due to the fact that the temperature of the glass in superheater zone 3 was about the same as that for the configuration 3 pour.

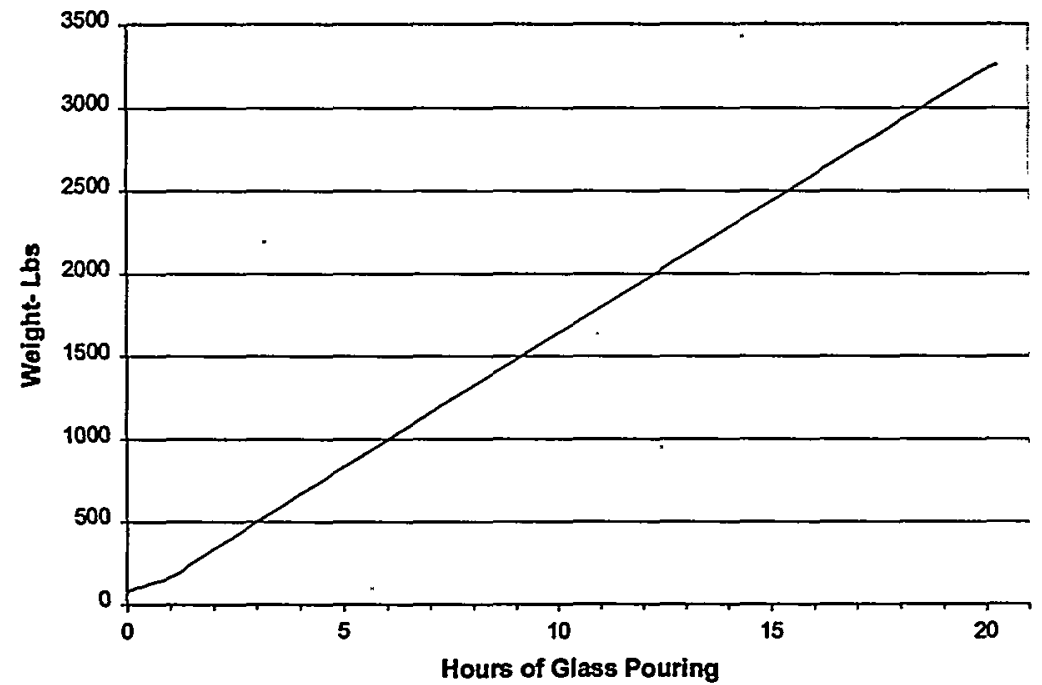

Figure $5.4-$ Glass Weight versus Time for Configuration 2 Canister 
In addition to the data gathered for the first two canisters, the configuration 2 canister had 23 thermocouples and a camera which viewed the inside of the canister during glass pouring. Details of the temperature data are given in the next section. The camera showed that the glass flowed from the centerline of the canister to the outside of the magazines. Sometimes the glass would flow around one magazine and then around the outside of several adjacent magazines before returning back to the centerline of the canister at a different location. This observation indicated that glass voiding was not occurring in this canister. This agreed with the comparison of the calculated and measured glass poured weights for this particular canister. Finally, the oxidation layers on all three canisters (see Figure 5.5) were typical to DWPF canisters after being filled. This observation gave yet more confidence that problematic glass voiding had not occurred. With regards to hardware deformation, the video showed that the hardware remained intact during the filling of the canister.

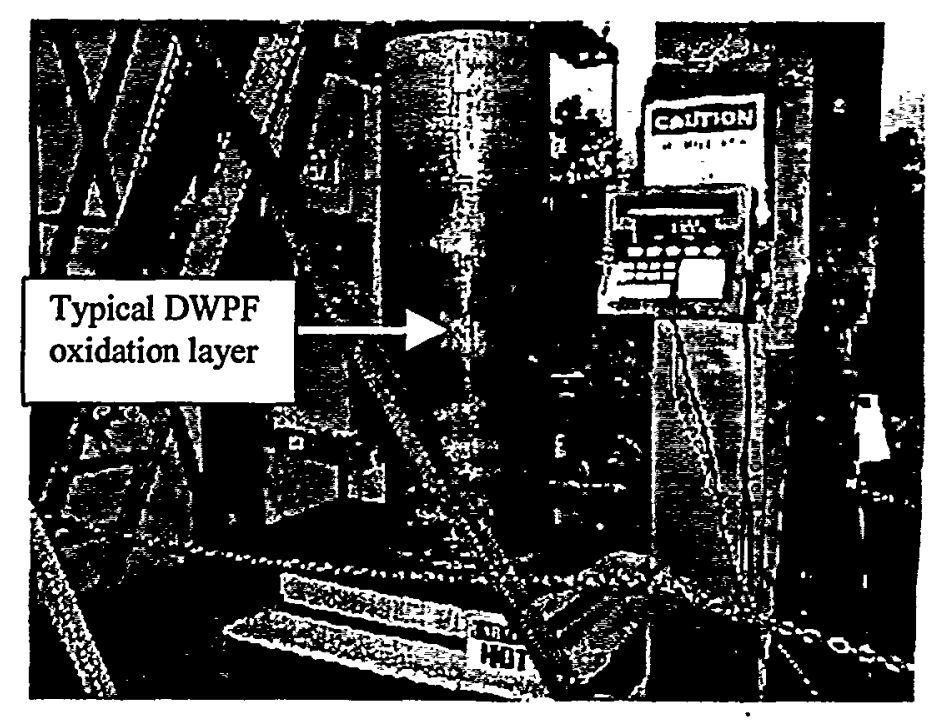

Figure 5.5 - Configuration 3 Canister during Pouring with Oxide Layer

As observed in the pre-pour tests, the glass tended to flow in a random pattern. In other words, the glass did not flow uniformly as would water or molten metals but fills a portion of the canister before moving to another section on the same horizontal plane. 


\subsection{Instrumented Canister (Configuration 2) Temperature Results}

The configuration 2 canister was instrumented with 23 type K 304 thermocouples sheathed in 304 stainless steel closed end tubes. The thermocouples were used to determine the thermal profile of the canister during glass pouring with the can-in-canister hardware. This data was to be used as well to help validate and improve the ProCast model being developed by LLNL. One thermocouple was welded to the bottom of the outside of the canister. Six thermocouples were welded to the outside of the canister at heights of 28,54 , and 84 inches (two located $180^{\circ}$ apart at each height). Five thermocouples were inserted through the canister to a radial location of 6 inches from canister centerline and at canister heights of 12,24,44,64, and 84 inches. Five more thermocouples were inserted through the canister to a radial location of 10.5 inches from canister centerline and at canister heights of 12,24, 44,64, and 84 inches. Two thermocouples were welded to the radial outside and inside of three different cans on magazine 2 at heights of 24,44 , and 84 inches (six total thermocouples). Table 6.1 gives more details on the placement of these thermocouples.

The output from the thermocouples was recorded on the same data acquisition system that stored the weight data for the three canisters. Data was taken every five minutes during glass pouring and every 30 minutes during cool down for 24 hours completion of pouring. Due to the data sampling interval, it is therefore possible that slightly higher temperatures occurred in the canister than those recorded.

Table 6.1 - Thermocouple Locations for Instrumented Configuration 2 Canister

\begin{tabular}{|c|c|c|c|c|}
\hline TC ID & Description & $\begin{array}{c}\text { Axial } \\
\text { Location* }\end{array}$ & $\begin{array}{c}\text { Angular } \\
\text { Location (degrees)** }\end{array}$ & $\begin{array}{c}\text { Radial } \\
\text { Location*** }\end{array}$ \\
\hline T1.1 & Glass temperature & $12^{\prime \prime}$ & 26 & $6^{\prime \prime}$ \\
\hline T1.2 & Glass temperature & $24^{\prime \prime}$ & 26 & $6^{\prime \prime}$ \\
\hline T1.3 & Glass temperature & $44^{\prime \prime}$ & 26 & $6^{\prime \prime}$ \\
\hline T1.4 & Glass temperature & $64^{\prime \prime}$ & 26 & $6^{\prime \prime}$ \\
\hline T1.5 & Glass temperature & $84^{\prime \prime}$ & 26 & $6^{\prime \prime}$ \\
\hline T2.1 & Glass temperature & $12^{\prime \prime}$ & 77 & $10.5^{\prime \prime}$ \\
\hline T2.2 & Glass temperature & $24^{\prime \prime}$ & 77 & $10.5^{\prime \prime}$ \\
\hline T2.3 & Glass temperature & $44^{\prime \prime}$ & 77 & $10.5^{\prime \prime}$ \\
\hline T2.4 & Glass temperature & $64^{\prime \prime}$ & 77 & $10.5^{\prime \prime}$ \\
\hline T2.5 & Glass temperature & $84^{\prime \prime}$ & 77 & $10.5^{\prime \prime}$ \\
\hline T3.1 & Canister surface & $28^{\prime \prime}$ & 334 & $12^{\prime \prime}$ \\
\hline T3.2 & Canister surface & $54^{\prime \prime}$ & 334 & $12^{\prime \prime}$ \\
\hline T3.3 & Canister surface & $84^{\prime \prime}$ & 334 & $12^{\prime \prime}$ \\
\hline T4.1 & Canister surface & $28^{\prime \prime}$ & 154 & $12^{\prime \prime}$ \\
\hline T4.2 & Canister surface & $54^{\prime \prime}$ & 154 & $12^{\prime \prime}$ \\
\hline T4.3 & Canister surface & $84^{\prime \prime}$ & 154 & $12^{\prime \prime}$ \\
\hline T5 & Canister bottom & $2{ }^{\prime \prime}$ & Center & Center \\
\hline T6.1 & Can temperature & $24^{\prime \prime}$ & 0 & $9.3^{\prime \prime}$ \\
\hline T6.2 & Can temperature & $44^{\prime \prime}$ & 0 & $9.3^{\prime \prime}$ \\
\hline T6.3 & Can temperature & $84^{\prime \prime}$ & 0 & $9.3^{\prime \prime}$ \\
\hline T7.1 & Can temperature & $24^{\prime \prime}$ & 0 & $6.3^{\prime \prime}$ \\
\hline T7.2 & Can temperature & $44^{\prime \prime}$ & 0 & $6.3^{\prime \prime}$ \\
\hline T7.3 & Can temperature & $84^{\prime \prime}$ & 0 & \\
\hline & & & 0 & \\
\hline
\end{tabular}

*Axial location is measured from lowest point on canister bottom

**Angular location is measured counterclockwise from the center of the cans with thermocouples (these cans were located in magazine 2)

***Radial location is measured from center of canister 
Figures 6.1 through 6.5 plot the temperature data for the various thermocouple locations during glass pouring. Figure 6.1 gives the temperature of the outside bottom of the canister. The temperature is fairly cool in comparison to the glass stream. Figure 6.2 plots the various measured outside surface canister temperatures. The maximum temperatures were achieved for all three thermocouple heights just as the glass reached those respective levels in the canister. The differences in timing of the maximum temperatures for the various levels (for example - T3.1 versus T4.1) gives more evidence that the glass tended to flow from side to side during filling of the canister as seen in the previously discussed pre-phase 1 tests and from the video observation of the Configuration 2 glass pour.

Figure 6.3 plots the temperatures of the glass inside the canister 6 inches from the canister centerline at various glass heights. As with Figure 6.2, the maximum glass temperatures occur as the glass level reaches the various thermocouples. The key point here is that the maximum glass temperature measured was almost $1000^{\circ} \mathrm{C}$. This agrees well with the measured glass stream temperature of about $1080^{\circ} \mathrm{C}$ as it flows into the top of the canister. Figure 6.4 plots the temperatures of the glass inside the canister 1 inch from the canister wall. Again maximum temperatures occurred as the glass level reaches the various thermocouples. On Figures 6.2, 6.3, and 6.4, the maximum temperatures were obtained with a sharp rise in temperature and then a less steep drop in temperature. Finally, Figure 6.5 plots the temperatures of various can surfaces during glass pouring. The figure shows that there is about a $100^{\circ} \mathrm{C}$ temperature drop between the surface of the can closest to the canister centerline and the can surface furthest away from the canister centerline. A final observation is that the maximum observed can temperatures were well below that in which the stainless steel would be expected to fail due to it weakening at elevated temperatures.

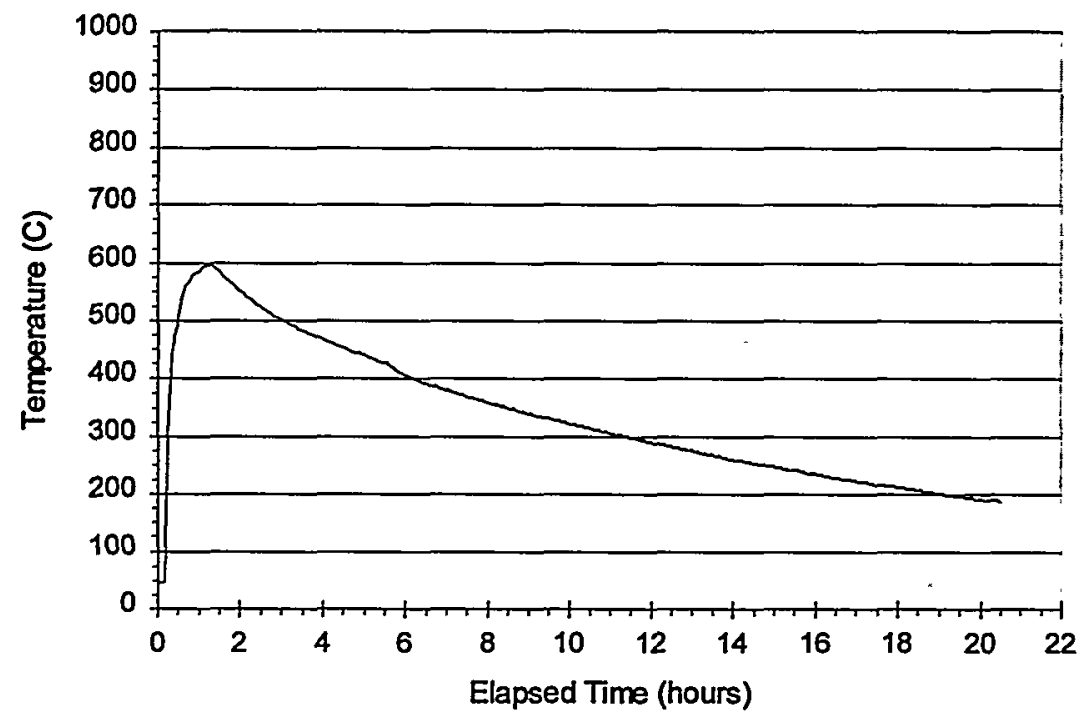

Figure 6.1 - Canister S00167 Outside Surface Bottom Temperatures during Glass Pouring 


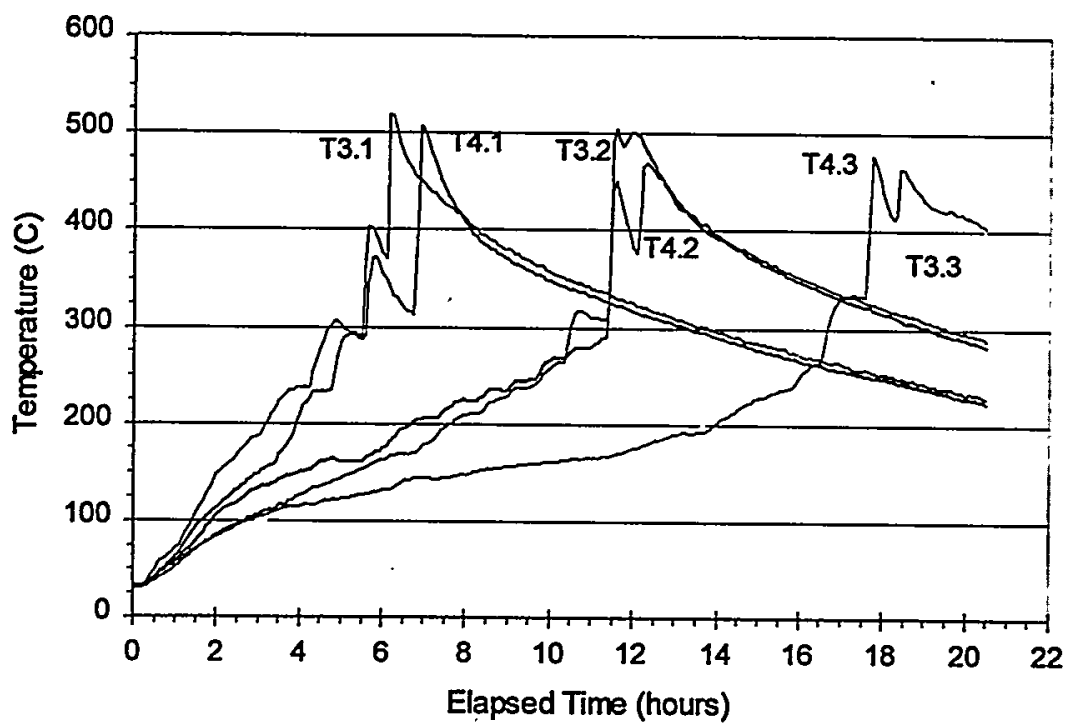

Figure 6.2 - Canister S00167 Outside Surface Temperatures during Pouring

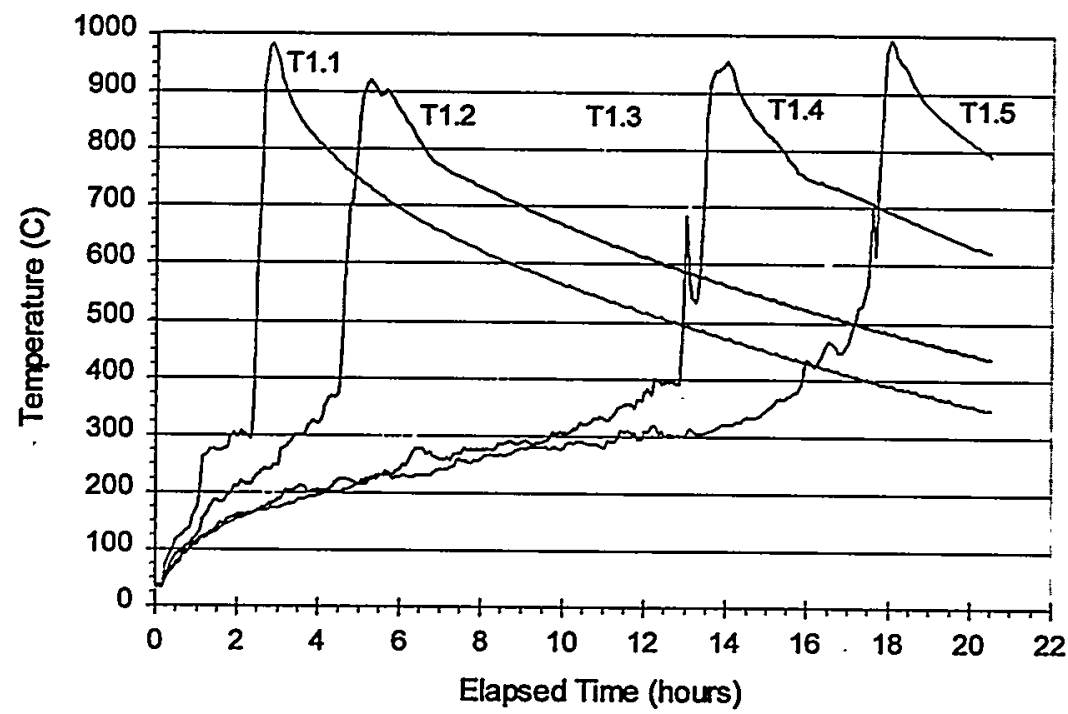

Figure 6. 3 - Canister S00167 Glass Temperatures 6" from Centerline during Pouring 


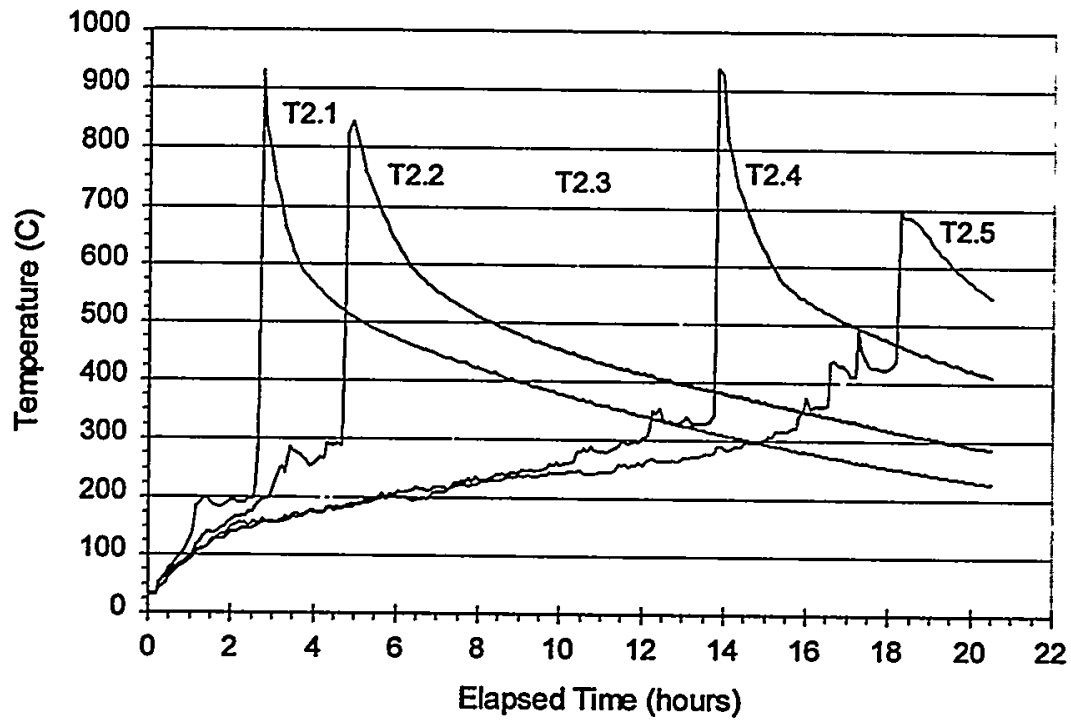

Figure 6.4 - Canister S00167 Glass Temperatures 1” from Inside Canister Wall during Pouring

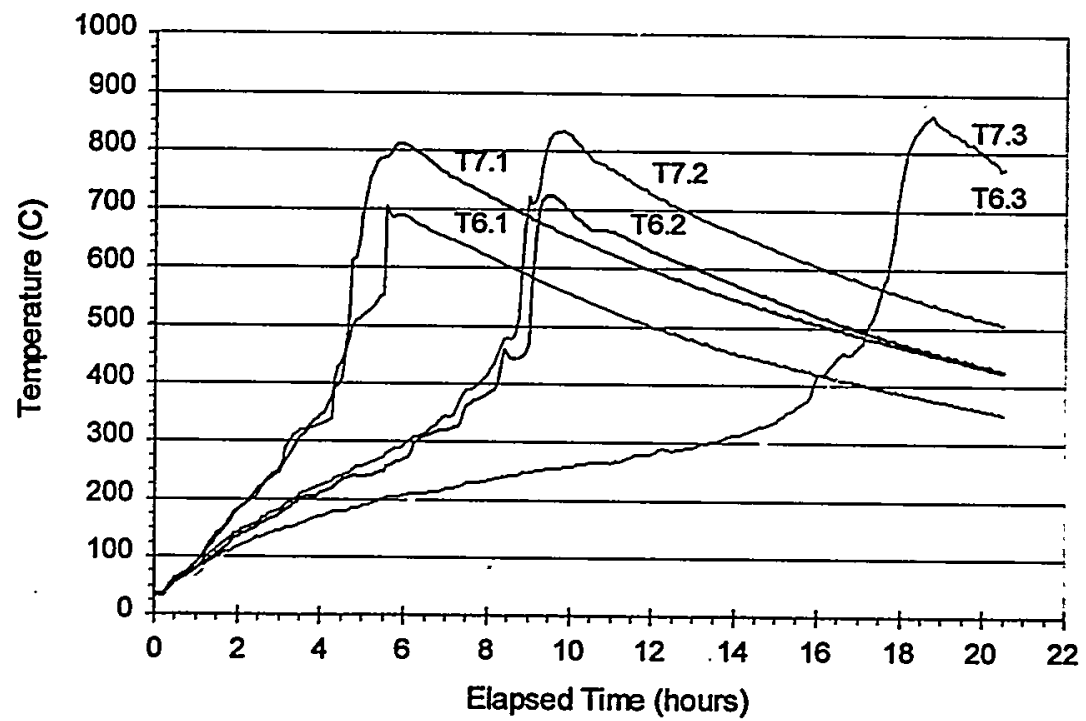

Figure 6.5 - Can Surface Temperatures during Glass Pouring of Canister S00167 


\subsection{Canister Sectioning}

After the three canisters were filled with glass at the CETL, they were shipped to Keystone Memorials of Elberton, Georgia for sectioning. SRTC personnel marked the cross-section locations on the canisters before they were cut. After cutting the canisters, they were to be inspected by SRTC personnel to determine the extent of glass voiding and hardware integrity. Unfortunately, due to the toughness of the internal hardware plus glass, Keystone's equipment (six and ten foot circular saws) was unable to achieve the cuts. Therefore, two future actions were taken. The configuration 3 (heavy-duty hardware) canister was shipped to Trentec of Cincinnati, Ohio. Trentec uses a diamond wire rope technique to cut various materials. The other two canisters were shipped back to TNX at SRS to be cut by a large band saw that had been used to section DWPF canisters. The cut heights were prescribed in the Phase 1 test plan, but various problems caused these heights to be changed during the canister cuttings. Photographs were taken of all canister cross-sections. The sectioning of the three canisters is discussed below.

\subsection{Configuration 3 Canister Sectioning}

Trentec successfully sectioned the heavy-duty configuration 3 canister at four different canister heights. These heights were 5.75, 26,33, and 66 inches. The 5.75 inch cut height was just above the bottom socket plate. Due to the use of the diamond wire technique, the cuts were somewhat ragged in appearance versus previous cuts made by the TNX canister band saw on DWPF canisters without the CIC hardware. Figure 7.1 shows a typical canister cross-section. General observations are as follows:

1. At the 5.75 inch cut, no glass voids were seen in the canister region. Only the interior of the magazine cones did not flood with glass.

2. At the 5.75 inch cut, the glass below the bottom socket plate did not wet the stainless steel surfaces.

3. With the remaining cuts, there were still no signs of glass voids.

4. There was good glass flow into the region between the cans and the magazines (see Figure 7.2 for an example of this). Cans were tightly held in place and could not be removed by hand.

5. There was less glass cracking near the centerline of the canister.

6. There was no observable deformation of the canister hardware.

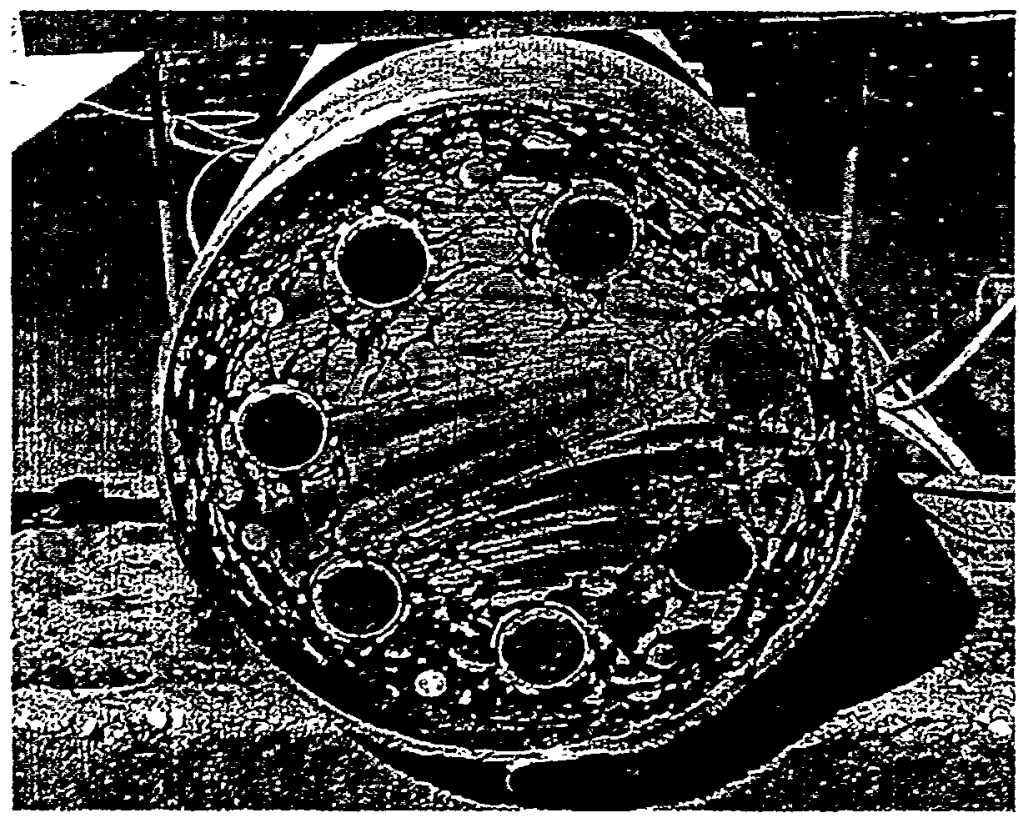

Figure 7.1 - Cross-Section of Configuration 3 Canister at 33" Height 


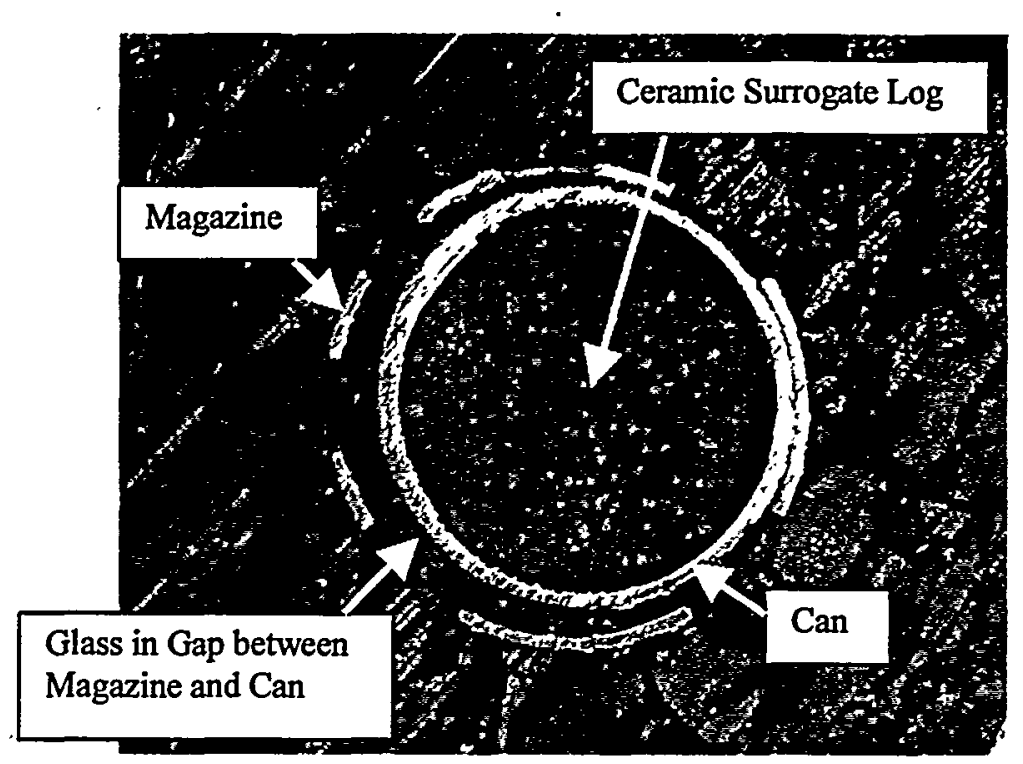

Figure 7.2 - Typical Cross-Section of Magazine and Can (Configuration 1 Canister with Schedule 10 Pipe Short Slots Magazine)

\subsection{Configuration 1 Canister Sectioning}

After repairing the TNX band saw, the configuration 1 canister was sectioned at canister heights of 8 and 26 inches. The results from the configuration 1 canister sectioning were consistent with the previous configuration 3 canister results. In other words, there were no signs of glass voids or observable canister hardware deformation. The lack of glass voids was significant because this canister had the worst case pour rate $(100 \mathrm{lbs} / \mathrm{hr})$ tested in Phase 1. A small glass void was found at the top of the glass level in the centerline of the canister, but this was typical of low pour rate DWPF canisters and was, therefore, not attributed to the canister hardware.

\subsection{Configuration 2 Canister Sectioning}

The configuration 2 canister was the last to be sectioned at TNX. The cuts were made at canister heights of $5.75,23,46$, and 66 inches. Again, there were no signs of glass voids or observable canister hardware deformation.

\subsection{Post Sectioning Hardware Analysis}

After the canisters were sectioned and visually inspected, the CIC hardware was measured to determined if it had experienced any plastic deformation during the test. Attached memo SRT-RSE-99-00056 summarizes this work. The conclusion was that the CIC hardware did not experience measurable plastic deformation during the pour or as the glass cooled.

\subsection{Canister Glass Samples}

Glass samples were taken from each of the three canisters after they were filled. The configuration 1 and 3 glass samples were both obtained from the lowest canister height cross-sections. The configuration 2 canister had not been cross-sectioned when the samples were taken, so glass was sampled via the canister neck (top of canister). The SRTC Mobile Laboratory analyzed portions of these three samples for weight 
percent oxides. Only the major glass components that impact glass viscosity were measured. Table 8.1 shows the results of these analyses as well as the calculated viscosity of the glass at $1150^{\circ} \mathrm{C}$.

The calculated viscosity for the configuration 3 glass (62.6) does not agree well with the other two samples (79.9 and 78.2 poise for configurations 1 and 2). The glass should have been similar because the configuration 3 canister was filled between the other two canisters. Therefore the viscosity should also have been similar. The best explanation is that the measured oxide weight percent of $\mathrm{Li}_{2} \mathrm{O}$ for the configuration 3 glass was too high. Small increases in the amount of $\mathrm{Li}_{2} \mathrm{O}$ greatly lower the viscosity of the glass. The chemical composition results are consistent with nominal DWPF compositions.

Table 8.1 - Oxide Weight Percents and Calculated Viscosities (at $1150{ }^{\circ} \mathrm{C}$ ) for Phase 1 Test Glass

\begin{tabular}{|c|c|c|c|}
\hline \multicolumn{4}{|c|}{ Oxide Weight Percents } \\
\hline $\begin{array}{c}\text { Canister } \\
\text { Configuration }\end{array}$ & 1 & 2 & 3 \\
\hline$\overline{\mathrm{B}_{2} \mathrm{O}_{3}}$ & 786 & 805 & 824 \\
\hline $\mathrm{Li}_{2} \mathrm{O}$ & 3.63 & 3.57 & 4.02 \\
\hline $\mathrm{Na}_{2} \mathrm{O}$ & 10.7 & 10.1 & 10.2 \\
\hline $\mathrm{K}_{2} \mathrm{O}$ & 3.01 & 2.98 & 3.10 \\
\hline $\mathrm{MgO}$ & 1.56 & 1.49 & 1.48 \\
\hline $\mathrm{MnO}$ & 2.97 & 2.88 & 2.84 \\
\hline$\overline{\mathrm{Al}_{2} \mathrm{O}_{3}}$ & 5.90 & 5.82 & 5.62 \\
\hline $\mathrm{SiO}_{2}$ & 51.6 & 50.2 & 49.6 \\
\hline $\mathrm{Fe}_{2} \mathrm{O}_{3}$ & 9.67 & 9.96 & 10.0 \\
\hline $\mathrm{ZrO}_{2}$ & 0.957 & 0.91 & 0.890 \\
\hline Coloplot & & & \\
\hline $\begin{array}{l}\text { Calculated } \\
\text { Viscosities } \\
\text { (Poise) }\end{array}$ & 79.9 & 78.2 & 62.6 \\
\hline
\end{tabular}

Portions of each of the samples (about 500 grams) were also sent to PNNL so that the glass viscosities could be measured by a viscometer. The measured viscosities (at $1150^{\circ} \mathrm{C}$ ) for the configuration 1,2 , and 3 glasses were 56,56 , and 54 poise respectively. From past experience the measured viscosities of DWPF type glasses are usually lower (10 to 20 poise) than the predicted values. All of these glass viscosities are therefore in the range expected (see Section 5.1).

\subsection{Conclusions}

The Can-in-Canister System ( 7 magazine/28 cans) was tested during the Phase 1 scoping tests at the Clemson Environmental Technologies Laboratory by SRTC personnel. Three canisters with different hardware designs were filled under various DWPF pour conditions. Comparisons of predicted glass pour weights with measured glass weights in the canisters, the filming of the inside of one canister during glass filling, and subsequent cross sectioning and inspections of the canisters showed little (if any) glass voiding or hardware deformation. Subsequent measurements of the hardware after the initial visual inspections verified that the hardware did not experience measurable plastic deformation during the test.

In addition, temperature data from the instrumented canister indicates that the cans will not reach temperatures that could result in the rupture of the cans that house the plutonium containing ceramic pucks.

Therefore, the CIC System was proven to be a viable option for the disposition of excess weapons grade plutonium. The results of this Phase 1 Test will be used to determine the "final" CIC hardware design to be tested in the Phase 2 test. This Phase 2 Test will be performed to demonstrate compliance with the 
requirements specified in the Plutonium Immobilization Product Specifications (PIPS). One canister containing the "final" CIC hardware may also be filled in Phase 2 for testing related to the proliferation resistance of the CIC form.

\subsection{Acknowledgements}

Many people have contributed to the success of the Phase 1 Test. Mike Smith was the Task Leader for the actual test run at the CETL. Mitchell Stokes was the PIP Second Stage Technical Lead for the CIC hardware. Gregg Hovis was the coordinator of the CIC hardware efforts at the CETL and was responsible for the development of the original rack concept into the present configuration. Lee Hamilton was responsible for magazine procurement and aided in the hardware installation at the CETL. Harriet Haynes did the detail drawings for the CIC hardware. Brian Fiscus oversaw much of the canister cutting work. Dennis Bickford, Johnetta George, Tim Jones, and Don Miller supplied shift coverage during the tests. Robert Jones of NMSS was the main plant contact for this work. Frank Heckendorn supplied the viewing camera for the instrumented canister. Zafar Qureshi and Vernon Bush provided the support for the installation of the thermocouples in the instrumented canister as well as the data acquisition system. Steve Loflin and Kathy Mottel provided guidance on quality assurance issues. Clyde Ward gave overall support throughout the planning of the test. Don Erich (director of the CETL) and John Harden (CETL test lead) directed all of the CETL efforts for this run.

A special acknowledgement if offered to Dennis Bickford and Erich Hansen who worked for many months to get the DWPF Full-Scaled Stirred Melter ready for this and other tests at the CETL. Randy Singer and Dan Iverson also helped in the efforts to make this melter operational.

\subsection{References}

1. "Task Technical and QA Plan: Plutonium Immobilization Can-in-Canister Cold Pour Tests (U)", WSRC-RP-98-01347, Rev. 0, M. E. Smith, November 12, 1998.

2. "Milestone C.3-2 Annual Report on Clemson/INEEL Melter Work, Milestone C.1-3 Status of Replacement Heater Modules for Pour Spout Heater", WSRC-TR-99-00305, Rev. 0, D. F. Bickford, et al., August 30, 1999.

3. "Summary of Campaigns SGM-6 and SGM-7 of the DWPF Scale Glass Melter", DPST-87-532, P. D. Guidotti, et al., September 11, 1987. 


\section{ATTACHMENTS}


SRT-GEM-98-0040

Revision 0

CC: D. A. Crowley, 773-43A

C. R. Goetzman, 773-A

W. F. Ayres, 773-41A

K. Mottel, 773-43A

T. K. Snyder, 704-T

E. P. Maddux, 704-F

G. L. Hovis, 773-A

GFM Files

December 30, 1998

TO: D. Erich, CETL

D. T. Rankin, 773-A

R. H. Jones, 704-F

M. W. Stokes, 773-A

C. R. Ward, 773-A

Z. H. Qureshi, 786-5A

S. R. Loflin, 773-41A

J. F. Ortaldo, 704-S

T. Kan, LCNL

FROM: $\quad$ M. E. Smith, 773-43A

\section{EXPERIMENTAL TEST PLAN FOR PHASE 1 OF THE PIP CAN-IN-CANISTER COLD POUR TESTS (U)}

\section{INTRODUCTION}

A Task Technical and Quality Assurance Plan' detailing the task objectives, quality assurance, documentation, and responsibilities for the Plutonium Immobilization Project (PIP) Can-in-Canister Cold Pour Tests (PIP Task 2.7.1.2) has been written and approved. The TT \& QA Plan states the major objectives of these tests, but does not define the necessary operating parameters and other details for the tests. This experimental test plan addresses these issues for Phase 1 of the tests. Phase 2 will be covered in a separate test plan.

Phase 1 tests are scoping in nature and will be used to evaluate various rack/magazine configurations. Phase 1 tests will not be directly used for waste qualification activities requiring RW-0333P QA controls, but will be done under normal good laboratory practices. The actual pour tests will be done at the Clemson Environmental Technologies Laboratory (CETL) under WSRC Task Order Agreement Number KC36665-02. SRTC personnel will oversee all aspects of the pour tests as well as pretest and post-test activities of the cans, racks, magazines, and glass in the canisters. 
Three DWPF canisters with different magazine/rack configurations (SRT-RSE-98-0279 ${ }^{3}$ gives hardware configurations) will be filled with DWPF surrogate glass. The configuration 1 canister will be partially filled (30" of glass) with a low pour rate of $100 \mathrm{lb} / \mathrm{h}$ to get a worst case scenario for voids at the bottom of the canister. Configuration 2 and 3 canisters will be totally filled at a targeted pour rate of 200 to $240 \mathrm{lb} / \mathrm{h}$. The canisters will be filled from glass melted by the Full-Scale Stirred Melter located at the CETL. The task notebook to be used is WSRC-NB-98-00272.

\section{PRETEST ACTIVITIES}

1. The configuration 2 canister will be instrumented for thermocouples per Technical Task Request SRT-GFM-98-0036'. All required details of this instrumented canister are in the TTR. This configuration 2 canister will have a hardware configuration (magazines/racks/cans) per RSES document SRT-RSE-98-0279 .

2. Each of the three DWPF canisters to be used for Phase 1 testing will be cut one to two inches below the top dished head/canister cylinder weld to allow insertion of the racks, magazines, and cans. The SRTC Experimental Thermal Fluids Laboratory or their designee will cut the instrumented configuration 2 canister on site. The two other canisters will be cut offsite per WSRC Task Order Agreement Number KC36665-0². All canisters will have unique identification numbers.

3. The racks/magazines/ cans will be designed, fabricated, and measured by SRTC Remote and Specialty Equipment Systems (RSES) section personnel and other SRS personnel. Subcontractors may do some fabrication work. See SRT-RSE-98-0279 ${ }^{3}$ for equipment details and SRT-RSE-98-0275 for details concerning dimensional check information.

4. Plutonium surrogate pucks, stainless steel bars, or a ceramic surrogate supplied by LLNL (or a combination of these) will be loaded into each can. RSES and ITS personnel will determine the exact arrangement of these items before this activity is started. The cans will then have tops welded onto each of them by RSES or their designee. The cans will be numbered, and RSES will note what was loaded into each can. These cans will then be loaded into the various racks for configurations 1,2 , and 3 . The details of the contents in each can, as well as the-location of the cans in each configuration will be noted in the task notebook.

5. The various racks/magazines will then be loaded into the three canisters. The configuration 2 canister will be loaded at SRS while the configuration 1 and 3 canisters will be loaded at the CETL or at their subcontractor's shop.

6. After the loading of the racks/magazines, the tops of the canisters will be rewelded back onto the canisters. The configuration 2 canister will be rewelded at SRS while configuration 1 and 3 canisters will be rewelded at the CETL or at their subcontractor's shop. These welds do not need . to be full penetration, as the canisters will not be lifted at the canister throats.

QA SURVEILLANCE POINTS - The loading of the cans into the magazines and the placement of the racks/magazines into the canisters are $Q A$ surveillance points and require SRTC QA personnel as well as the appropriate RSES and ITS SRTC researchers prior to release for further work. 
Details of the preparation of the Stirred Melter and auxiliary equipment at the CETL are given in WSRC Task Order Agreement Number KC36665- $0^{2}$. The activities that must be done at the CETL before the Phase 1 tests can begin include the following:

Note: Organizations names in ()'s indicate the responsible group for completing the task.

1. Remove the DWPF pour spout test stand to allow filling of full sized DWPF canisters (CETL).

2. Engage the superheater to the main pot (CETL).

3. Install a feed delivery system that is capable of controlling the glass feed rate to the melter at 100 to $240 \mathrm{lb} / \mathrm{h}$ (CETL/SRTC-ITS).

4. Install canister weigh stand with scale under pour valve that can weigh up to 5500 pounds (CETL). Calibration of the scale is required (CETL/SRTC-ITS).

5. Prepare 15,000 pounds of DWPF glass that can be fed to melter via feed system (CETL). This glass is DWPF cold runs glass and is now stored at the CETL.

6. Set the distance from the bottom of the pour valve to the top of the canister to greater than 10 inches to mimic the glass stream fall distance at DWPF (CETL).

NOTE: The distance from the bottom of the Stirred Melter pour valve to the floor is 157.5 inches. A DWPF canister is 118 inches tall. This gives a gap of 39.5 inches. There will be a yet to be determined weigh scale under the canister that will raise it off the floor. In comparison, the distance between the end of the actual DWPF Melter pour spout and the canister in the DWPF Melt Cell is 23.375 inches. It has been determined that the pour stream cools by about $2^{\circ} \mathrm{C}$ for every inch of free fall. Based on this information, if the gap between the bottom of the Stirred Melter pour valve and the top of the canister is greater than 10 inches, the difference in the glass stream temperature for the . two melters as it enters the DWPF canister should be minimal (less than $50^{\circ} \mathrm{C}$ ).

7. Install an insulated spool piece between the canister and the bottom of the pour valve to mimic the connection between the DWPF pour spout and the canister (CETL).

8. Install a type $\mathrm{K}$ thermocouple in the thermowell just before superheater pour valve (CETL). This thermocouple should have adequate vendor certification for the Phase 2 tests. The loop for this thermocouple must be calibrated as well (SRTC-ITS).

\section{PHASE 1 TEST GLASS POUURING ACTIVITIES AND DETAILS}

As previously discussed, three DWPF canisters with different magazine/rack configurations will be filled with DWPF surrogate glass. SRT-GFM-98-0034 6 was previously written which describes the controlled/monitored parameters for both Phase 1 and 2 tests. Further details are listed below in this section. The Stirred Melter will be operated under approved CETL procedures. Changes to these procedures may be required during the tests due to unforeseen problems and will be noted via "redlining". The startup of the Stirred Melter is not part of this test and it is assumed that the melter 
is in a condition that allows for the tests to begin. This includes ability to melt and pour glass at 200 $\mathrm{lb} / \mathrm{h}$ for extended periods of time ( 20 hours). The configuration 1 canister will be filled first, followed by the configuration 3 canister and then lastly the configuration 2 canister. This order will allow the instrumented (configuration 2) canister to cool undisturbed after being filled with glass without delaying the rest of the test.

1. Thermocoupled canister - The configuration 2 canister (see SRT-RSE-98-0279 ${ }^{3}$ will be instrumented with thermocouples by SRTC's Experimental Thermal Fluids group per Task Technical Request SRT-GFM-98-0036. A data acquisition system supplied by SRS will be used to store the data from the start of pour and up to 24 hours after end of pouring.

2. Pour rate/canister scale - The glass pour rate will be monitored with a canister weigh scale. The actual pour rate will be controlled by a dry feed system that uses a bin and an auger. A loop that uses the feed rate as its setpoint will control the auger speed. For configuration 1, the targeted pour rate will be $100 \mathrm{lb} / \mathrm{h}$. For configurations 2 and 3, the targeted pour rate will be 200 to 240 $\mathrm{lb} / \mathrm{h}$. SRS may supply a data acquisition system to store the pour rate data. If not, weight readings will be taken every half-hour to track the pour rate.

3. Glass composition - Existing glass from DWPF cold run canisters already at Clemson will be used.

4. Glass stream temperature - In zone three of the Stirred Melter superheater, there is a thermowell used to measure the glass temperature just before it exits the melter via the pour valve. The thermocouple will be used to monitor/control the glass stream temperature (targeted temperature is $1100^{\circ} \mathrm{C} \pm 25^{\circ} \mathrm{C}$ ).

5. Canister glass fill height - The fill height for the configuration 1 canister will be 30 inches. The configuration 2 and 3 canisters will be filled to a height of at least 90 inches. This minimum level will be above the top of the highest cans in the canister.

6. Canister camera - A camera will be mounted on the instrumented configuration 2 canister (on the top looking down) to view glass flow inside the canister during pouring.

\section{POST TEST ACTIVITIES}

After the canisters have been filled, canister configurations 2 and 3 will be cut at the heights of 5.5, 25,45 , and 65 inches (heights referenced from the bottom of the outside of the canisters) for inspection of the glass and configurations. Canister configuration 1 will only be cut at heights 5.5 and 13 inches due to it being only partially filled with glass. The technique used for the above cuts must be approved by the SRTC ITS lead and can not alter the number, location, or size of the glass voids or the existing deformation of the internal hardware. Techniques such as plasma torch cutting are therefore not acceptable. CETL personnel may do additional cuts to the canisters as instructed by the SRTC ITS lead using a plasma torch. The following items will be performed and noted in the task notebook. Other activities may also be done per RSES. 
1. Glass voids in canister - The glass inside the canisters will be inspected for any glass voids. Total coverage of the cans by glass (or lack of) will be especially noted. Photographs and or drawings will be made to document the presence of any voids.

2. Amount of glass cracking - The cross-sectioned canisters will be photographed to document glass cracking. The amount of glass cracking noted is for information only. The cutting of the canister will increase the amount of glass cracking, therefore an accurate evaluation may not be possible.

3. Puck composition changes/cracking - There is some interest in changes that may occur with the plutonium ceramic pucks during glass filling. Pucks supplied by LLNL (about 300) will be placed in cans and will be returned to LLNL for inspection/analysis.

4. Canister/rack/magazine/can dimensions - See SRT-RSE-98-0275' ("DWPF Canister Assembly Dimensions" section) for details concerning dimensional check information. RSES will determine and document any additional items inspected

5. Glass samples - Two glass samples (only one for the configuration 1 canister) will be taken from each canister filled and elemental data will be determined. This elemental data will then be used to determine the viscosity of the glass at $1150^{\circ} \mathrm{C}$ via existing models used by DWPF.

QA SURVEILLANCE POINTS - The cutting of the canisters, as well as the various inspections are $Q A$ surveillance points and require witnessing by SRTC $Q A$ personnel as well as the appropriate RSES and ITS SRTC researchers.

\section{REFERENCES}

1. "Task Technical and QA Plan: Plutonium Immobilization Can-in-Canister Cold Pour Tests", WSRC-RP-009.8-01347, M. E. Smith, November 12, 1998.

2. "Plutonium Immobilization Can-in-Canister Cold Pour Tests", WSRC Task Order Agreement Number KC36665-0, Rev. 0.

3. "Plutonium Immobilization Phase-1 Cold Pour Hardware Configurations", SRT-RSE-98-0279, G. L. Hovis, November 30, 1998.

4. "Technical Task Request: Instrumenting PIP Cold Pour Test Canister", SRT-GFM-98-0036, M. E. Smith, November 13, 1998.

5. "Plutonium Immobilization Cold Pour Test Component Dimension Check", SRT-RSE-98-0275, M. W. Stokes, November 17, 1998.

6. "Controlled/Monitored Parameters for the PIP Cold Pour Tests at Clemson (U), SRT-GFM-980034, M. E. Smith, December 7, 1998. 


\section{APPROVALS}

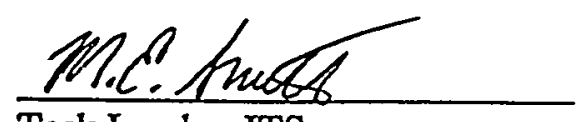

Task Leader, ITS

M. E. Smith

D. Themer Ralin

Level 4 Manager, ITS

$\mathrm{Pu}$ Immobilization Form \& Demo

D. T. Rankin

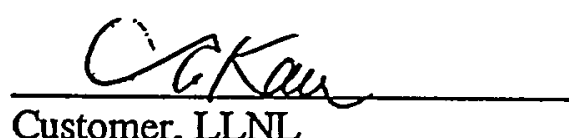

T. Kan

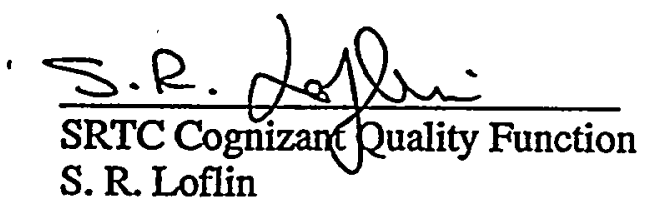

A20 clable

DWPF Engineering

J. F. Ortaldo

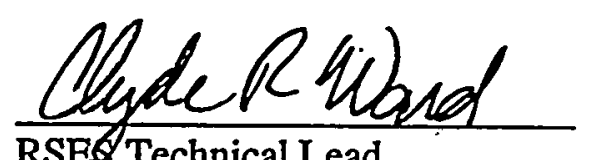

RSEO Technical Lead

C. R. Ward

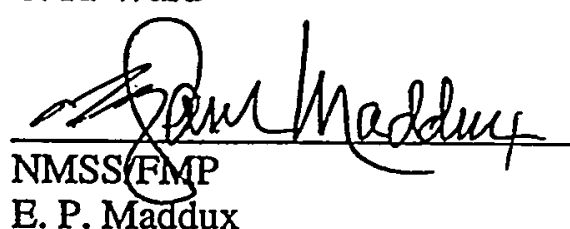

\section{2/2/99}

Date

$2 / 22199$

Date

$2 / 17 / 99$

Date

$\frac{2 / 8 / 99}{\text { Date }}$

$\frac{2 / 25199}{\text { Date }}$

$\frac{2 / 2 / 99}{\text { Date }}$

$\frac{712 / 99}{\text { Date }}$ 


\section{WESTINGHOUSE SAVANNAH RIVER COMPANY INTEROFFICE MEMORANDUM}

December 7, 1999

TO: M. E. Smith, 773-A .

FROM: L. Hamilton, 773-A, D-1012 EL甘
G. Hovis, 773-A, D-1105 (at)

\section{PU IMMOBIIZATION PHASE 1 COLD POUR - POST-POUR ANALYSIS}

Summary

Two Can-in-Canister assemblies were filled and another partially filled with simulated DWPF waste glass. These pours were conducted to test the efficiency of the magazine, rack and associated hardware designs, and to assess glass flow in the presence of can-in-canister hardware. Following the pours, the Can-inCanister assemblies were sectioned for inspection. A visual examination verified that the simulated waste glass filled small crevices in the magazines and completely filled the annular spaces between the magazines and cans, locking the cans into place. Hardware measurements taken at the section faces verified that the Can-in-Canister hardware did not experience measurable plastic deformation during the pour or later as the glass cooled.

\section{Preparation for Analysis}

Three poured Can-in-Canister assemblies consisting of the DWPF canister, rack, 7 magazines, and 28 cans were sectioned and measurements taken as shown on the following map:
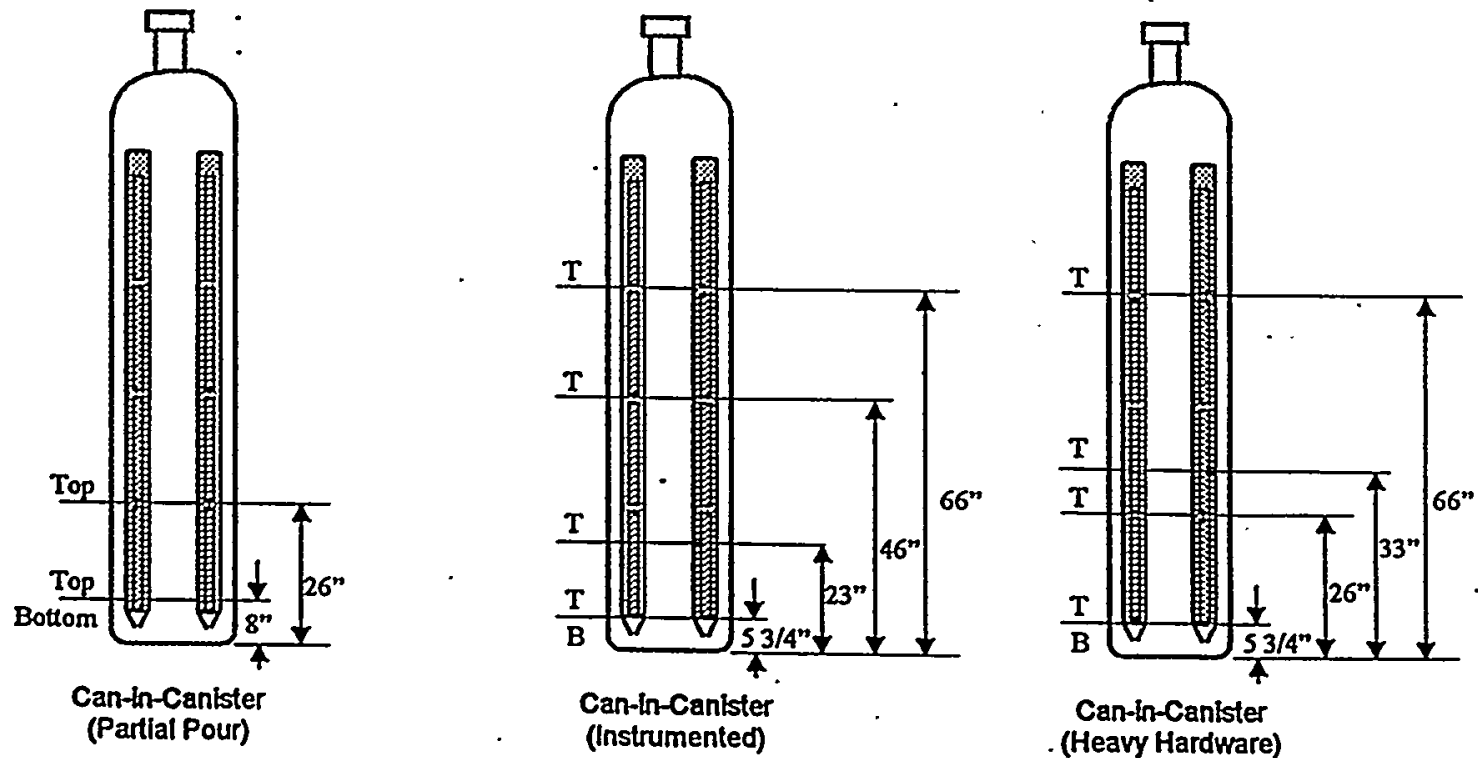

Can-in-Canister - (Heavy Hardware) 
At each slice, measurements were taken at the following locations:
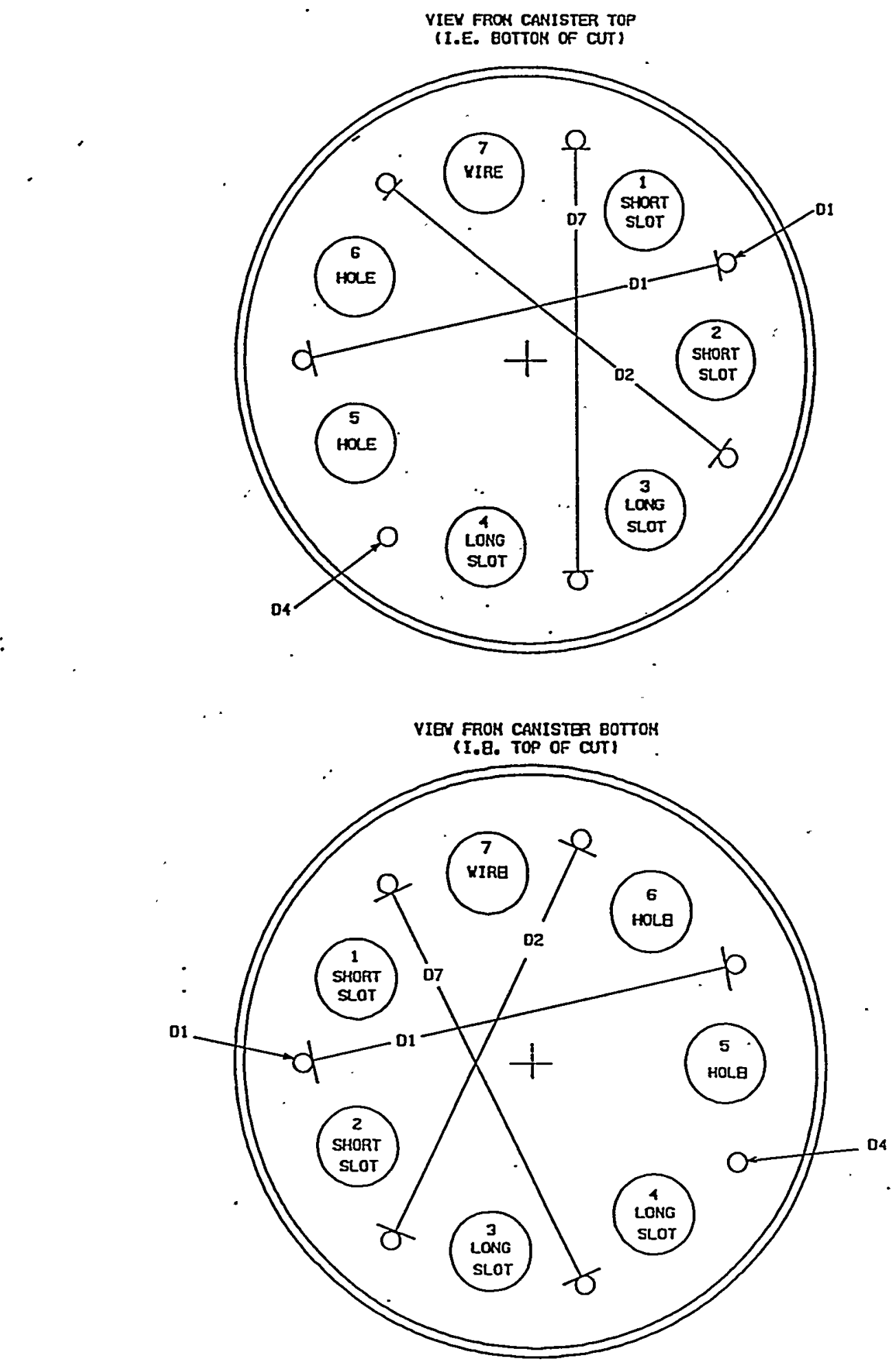

These measurements were recorded, as shown on the chart on the next page. 


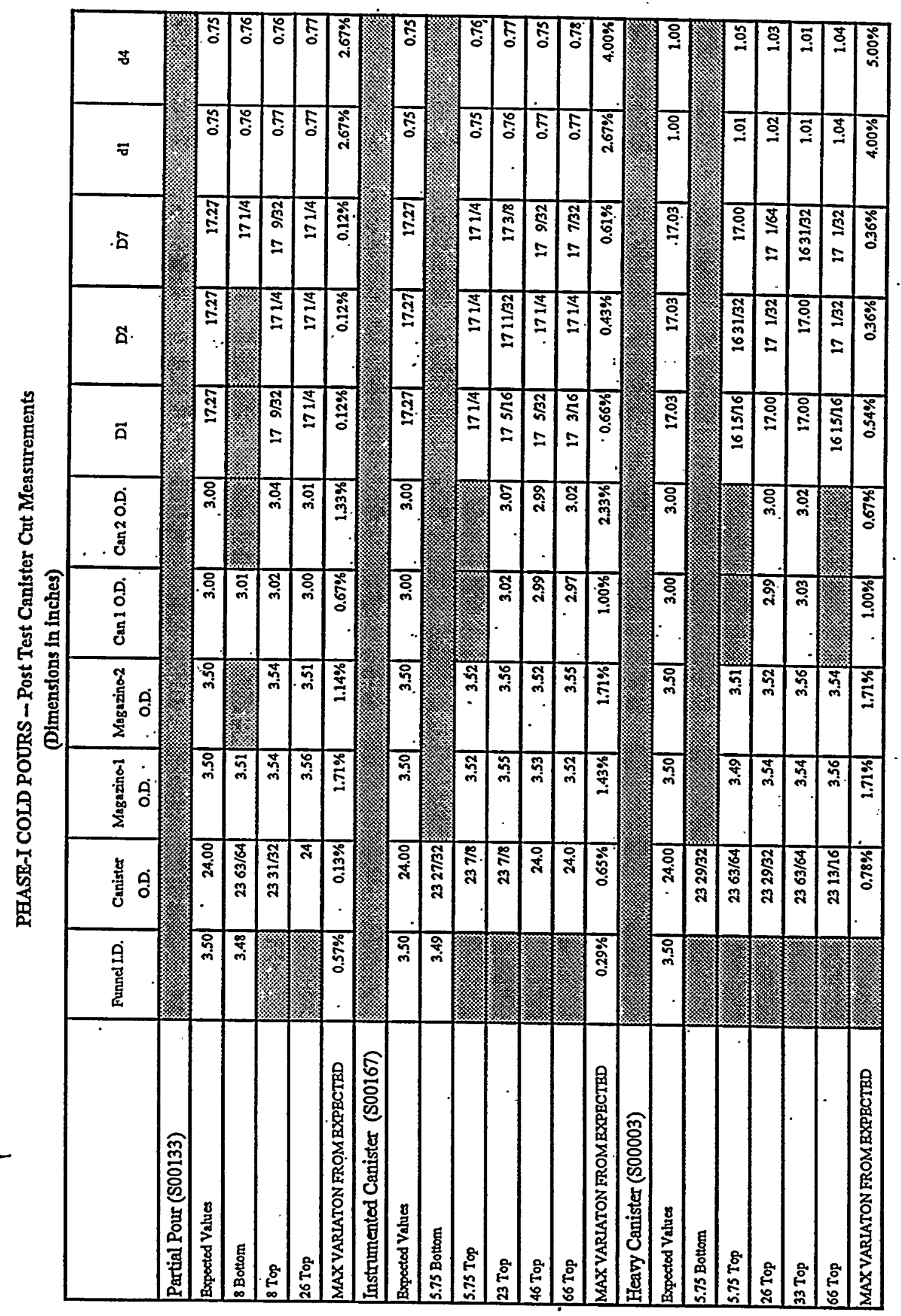


In the preceding table, decimal measurements were taken with a dial caliper, fractional measurements were taken with a tape measure. Some measurements could not be obtained because the cutting process had destroyed the item to be measured.

\section{Analysis of Results}

The canister, rack, magazines, cans and hardware do not experience significant plastic deformation during * glass pouring or cool down.

Though the rack, magazines, and cans were measured prior to pouring, cut locations deviated from the locations of pre-pour measurements due to concerns that the saw would be damaged if used to cut through free-rotating ceramic pucks. Therefore, pre-pour data was deemed irrelevant and post-pour measurements were compared to design requirements.

At each cut surface, post-pour values that indicate rack deformation (D1, D2, and D7) vary a maximum of $0.6 \%$ from design values. This is well within the combined effects of surface smearing during the cutting operation, measurement error and normal design tolerances, therefore it is clear that significant rack deformation did not occur. Likewise, final dimensions for magazines and cans vary little from design values.

The diamond rope saw smeared the metal components on the "heavy" canister assembly during the cutting process, producing a burr that averages 0.018 ." (The TNX bandsaw produced much less smearing and corresponding metal burr on the other two canisters'). When measurements were taken, the actual measurement (including the bur, if present) was recorded. Therefore, these measurements are greater than expected because design parameters do not include the burr.

This report only discusses measurements taken at the cut faces because the canisters are still filled with glass. Additional measurements could be taken after the glass is removed from the canisters, however it is not expected that these measurements would reveal any deformation. There is no indication from any of the measurements that plastic deformation occurred.

CC R. Jones, 704-F

Jim Marra, 773-43A

- M. W. Stokes, .723-A

C. Ward, 773-A

J. Wong, 773-A

STI, 70,3-43A

Job Folder 22624 (730-A) 


\section{DISTRIBUTION LIST}

L. M. Papouchado, 773-A

J. D. Cohen, 773-A

C. R. Wolfe, 773-A

E. W. Holtzscheiter, 773-A

S. L. Tibrea, 773-A

A. L. Blancett, 773-A

T. H. Gould, 773-41A

J. C. Marra, 773-43A

D. A. Crowley, 773-43A

S. L. Marra, 704-1T

L. F. Landon, 704-1T

J. W. Wong, 773-A

J. F. Ortaldo, 704-S

D. C. Iverson; 704-30S

E. P. Maddux, 704-F

R. H. Jones, 704-F

W. J. Randall, 704-F

M. E. Smith, 773-43A

G. L. Hovis, 773-A

M. W. Stokes, 723-A

C. R. Ward, 773-A

J. R. Brault, 723-A

E. M. Kriikku, 773-A

D. F. Bickford, 773-43A

T. M. Jones, 704-1T

J. C. George, 773-43A

D. H. Miller, 704-1T

D. C. Witt, 704-1T

E. L. Hamilton, 723-A

Z. H. Qureshi, 786-5A

J. B. Fiscus, 723-A

T. Kan, LLNL

W. Stein, LLNL 


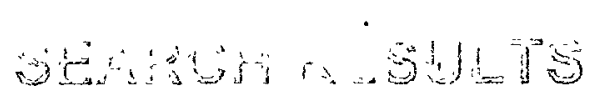

\begin{tabular}{|c|c|c|c|c|c|c|c|}
\hline OSTI ID & TITLE & AUTHOP & REPORT NUMBER & $\begin{array}{c}\text { CONTRACT } \\
\text { NUMBER }\end{array}$ & $\begin{array}{l}3 \pi \mathrm{E} \\
\cos \end{array}$ & STATUS & TE:T \\
\hline 750862 & $\begin{array}{l}\text { Can-in-Canister Cold } \\
\frac{\text { Pour Tests for the }}{\text { Plutonium }} \\
\text { Immobilization Project }\end{array}$ & $\begin{array}{l}\text { Smith, } \\
\text { M.E. }\end{array}$ & |WSRC-TR-99-00337| & DE-AC09-96SR 18500 & SRS & $\begin{array}{l}\text { Released } \\
\text { to OSTI }\end{array}$ & \\
\hline
\end{tabular}

\section{This search returned 7 record(s)}

